\title{
Special Analysis Air Pathway Modeling of E-Area Low-Level Waste Facility
}

\author{
Robert A. Hiergesell \\ Glenn A. Taylor
}

August 2011

Savannah River National Laboratory Savannah River Nuclear Solutions Aiken, SC 29808

Prepared for the U.S. Department of Energy under contract number DE-AC09-08SR22470.

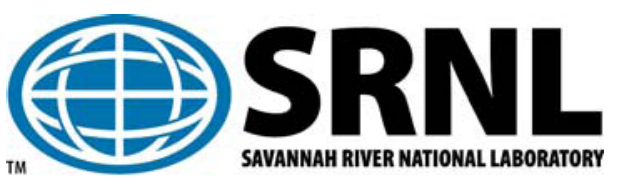


SRNL-STI-2011-00327

Revision 0

\section{DISCLAIMER}

This work was prepared under an agreement with and funded by the U.S. Government. Neither the U.S. Government or its employees, nor any of its contractors, subcontractors or their employees, makes any express or implied:

1. warranty or assumes any legal liability for the accuracy, completeness, or for the use or results of such use of any information, product, or process disclosed; or

2. representation that such use or results of such use would not infringe privately owned rights; or

3. endorsement or recommendation of any specifically identified commercial product, process, or service.

Any views and opinions of authors expressed in this work do not necessarily state or reflect those of the United States Government, or its contractors, or subcontractors.

Printed in the United States of America

Prepared for U.S. Department of Energy 
SRNL-STI-2011-00327

Revision 0

Keywords: $E L L W F$,

atmospheric, GoldSim ${ }^{\circledR}$, plume

overlap

Retention: Permanent

\title{
Special Analysis Air Pathway Modeling of E-Area Low-Level Waste Facility
}

\author{
Robert A. Hiergesell
}

Glenn A. Taylor

August 2011

Savannah River National Laboratory

Savannah River Nuclear Solutions

Aiken, SC 29808

Prepared for the U.S. Department of Energy under contract number DE-AC09-08SR22470. 
SRNL-STI-2011-00327

Revision 0

\section{REVIEWS AND APPROVALS}

\section{AUTHORS:}

Robert A. Hiergesell, Radiological Performance Assessment

Date

Glenn A. Taylor, Radiological Performance Assessment

Date

TECHNICAL REVIEW:

Frank G. Smith, Process Modeling \& Comp Chemistry

Date

\section{APPROVAL:}

David A. Crowley, Manager

Date

Radiological Performance Assessment

Robert Aylward, Manager

Date

Environmental Restoration Technology

Kevin M. Kostelnik, Deputy Director

Date

Regulatory Integration \& Environmental Services

Marshall G. Looper, SWM Chief Engineer

Date

Solid Waste Management Engineering

Dewitt L. Beeler, Solid Waste Facility Manager

Date

Solid Waste Management Facility 
SRNL-STI-2011-00327

Revision 0

\section{EXECUTIVE SUMMARY}

This Special Analysis (SA) was initiated to address a concern expressed by the Department of Energy's Low Level Waste Disposal Facility Federal Review Group (LFRG) Review Team during their review of the 2008 E-Area Performance Assessment (PA) (WSRC, 2008). Their concern was the potential for overlapping of atmospheric plumes, emanating from the soil surface above SRS LLW disposal facilities within the E-Area, to contribute to the dose received by a member of the public during the Institutional Control (IC) period. The implication of this concern was that the dose to the maximally-exposed individual (MEI) located at the SRS boundary might be underestimated during this time interval. To address this concern a re-analysis of the atmospheric pathway releases from E-Area was required. In the process of developing a new atmospheric release model (ARM) capable of addressing the LFRG plume overlap concern, it became obvious that new and better atmospheric pathway disposal limits should be developed for each of the E-Area disposal facilities using the new ARM. The scope of the SA was therefore expanded to include the generation of these new limits.

The initial work conducted in this SA was to develop a new ARM using the GoldSim ${ }^{\circledR}$ program (GTG, 2009). The model simulates the subsurface vapor diffusion of volatile radionuclides as they release from E-Area disposal facility waste zones and migrate to the land surface. In the process of this work, many new features, including several new physical and chemical transport mechanisms, were incorporated into the model. One of the most important improvements was to incorporate a mechanism to partition volatile contaminants across the water-air interface within the partially saturated pore space of the engineered and natural materials through which vapor phase transport occurs. A second mechanism that was equally important was to incorporate a maximum concentration of $1.9 \mathrm{E}-07 \mathrm{Ci} / \mathrm{m}^{3}$ of ${ }^{14} \mathrm{CO}_{2}$ in the air-filled pores of cementitious materials. The ARM also combines the individual transport models constructed for each E-Area disposal facility into a single model, and was ultimately used to analyze the LFRG concern regarding the potential for atmospheric plume overlap at the SRS boundary during the IC period.

To evaluate the plume overlap issue, a conservative approach was adopted whereby the MEI at the SRS boundary was exposed to the releases from all E-Area disposal facilities simultaneously. This is equivalent to a $100 \%$ overlap of all atmospheric plumes emanating from E-Area. Should the dose received from this level of atmospheric plume overlap still fall below the permissible exposure level of $10 \mathrm{mrem} / \mathrm{yr}$, then the LFRG concern would be alleviated. The structuring of the ARM enables this evaluation to be easily performed.

During the IC period, the peak of the "total plume overlap dose" was computed to be 1.9E-05 $\mathrm{mrem} / \mathrm{yr}$, which is five orders of magnitude lower than the $10 \mathrm{mrem} / \mathrm{yr}$ PA performance objective for the atmospheric release pathway. The main conclusion of this study is that for atmospheric releases from the E-Area disposal facilities, plume overlap does not cause the total dose to the MEI at the SRS boundary during the IC to exceed the Performance Assessment (PA) performance objective. Additionally, the potential for plume overlap was assessed in the post-Institutional Control period. Atmospheric plume overlap is less likely to occur during this period but conceivably could occur if the prevailing wind direction shifted so as to pass directly over all EArea disposal facilities and transport airborne radionuclides to the MEI at the $100 \mathrm{~m}$ point of compliance (POC). This concern was also demonstrated of little concern, as the maximum plume overlap dose was found to be $1.45 \mathrm{E}+00 \mathrm{mrem} / \mathrm{yr}$ (or $\sim 15 \%$ of the performance measure) during this period and under these unlikely conditions. 
Using the improved ARM it was discovered that, even though the full suite of potentially volatile radionuclides were introduced into the model, it computes a zero flux at the land surface for all of the radionuclides except $\mathrm{C}-14$ and $\mathrm{H}-3$. The main factors in this phenomenon are the tendency of those radionuclides to partition into the available pore water of the disposal facility layers and overlying layers during the simulation and radioactive decay. As a result, air pathway disposal limits that were established in the $2008 \mathrm{PA}$, for radionuclides other than C-14 and H-3, no longer apply. This SA presents a new set of atmospheric disposal limits for the E-Area disposal facilities for C-14 and H-3. Special waste forms are considered to have the same disposal limit as the updated generic radionuclide disposal limits with the exception of the H3_TPB and H3_IP-2 special waste forms that will be disposed in the ILV. Both of these waste forms are steel disposal containers that are welded shut and contain tritium from the SRS Tritium Extraction Facility. For these, the H3_IP-2 and H3_TPB waste forms disposal limits established in the 2008 PA and in Swingle, $2008 \mathrm{~b}$ still apply. These limits are $4.6 \mathrm{E}+08 \mathrm{Ci}$ and $9.4 \mathrm{E}+10 \mathrm{Ci}$ for the two special waste forms, respectively.

Table ES-1. Summary of the PA and New Atmospheric Pathway Disposal Limits for E-Area Facilities

\begin{tabular}{|c|c|c|}
\hline & $\begin{array}{l}\text { PA Atm. Pathway } \\
\text { Disposal Limit } \\
\text { (Ci/unit) }\end{array}$ & $\begin{array}{l}\text { New Atm. Pathway } \\
\text { Disposal Limit } \\
\text { (Ci/unit) }\end{array}$ \\
\hline C-14 in Slit East ${ }^{1}$ & $2.9 \mathrm{E}+05$ & $1.9 \mathrm{E}+05$ \\
\hline C-14 in Slit West ${ }^{1}$ & $2.9 E+05$ & $1.9 E+05$ \\
\hline C-14 in Slit Center ${ }^{1}$ & $2.9 \mathrm{E}+05$ & $1.9 \mathrm{E}+05$ \\
\hline C-14 in ET & $2.9 \mathrm{E}+05$ & $1.9 \mathrm{E}+05$ \\
\hline H-3 in Slit East ${ }^{1}$ & $1.1 \mathrm{E}+07$ & $2.8 \mathrm{E}+18$ \\
\hline H-3 in Slit West ${ }^{1}$ & $1.1 \mathrm{E}+07$ & $2.8 \mathrm{E}+18$ \\
\hline H-3 in Slit Center ${ }^{1}$ & $1.1 \mathrm{E}+07$ & $2.8 \mathrm{E}+18$ \\
\hline H-3 in ET & $1.1 \mathrm{E}+07$ & $2.8 \mathrm{E}+18$ \\
\hline C-14 in CIG & $1.7 \mathrm{E}+06$ & $3.4 \mathrm{E}+09$ \\
\hline $\mathrm{H}-3$ in $\mathrm{CIG}$ & $3.1 \mathrm{E}+07$ & --- \\
\hline C-14 in ILV & $2.2 \mathrm{E}+05$ & $7.4 \mathrm{E}+08$ \\
\hline $\mathrm{H}-3$ in ILV & $3.8 \mathrm{E}+06$ & $6.4 \mathrm{E}+18$ \\
\hline C-14 in LAW & $3.3 \mathrm{E}+03$ & $3.5 \mathrm{E}+09$ \\
\hline H-3 in LAW & $1.1 \mathrm{E}+08$ & $3.8 \mathrm{E}+13$ \\
\hline C-14 in NRCDA $643-26 E$ & $2.6 \mathrm{E}+03$ & $1.0 \mathrm{E}+04$ \\
\hline C-14 in NRCDA $643-7 E$ & $5.3 E+02$ & $4.9 \mathrm{E}+03$ \\
\hline
\end{tabular}

Note: ${ }^{1}$ The new limits apply to each trench unit within the East, Center and West grouping of trenches

The analysis conducted included a review of the four SA's and ten Unreviewed Disposal Question Evaluation's (UDQE's) performed since the 2008 PA was issued to determine if they impose any conditions that impact the air pathway evaluated in this SA. No such conditions were identified. Those reports are listed individually in Section 6. 


\section{TABLE OF CONTENTS}

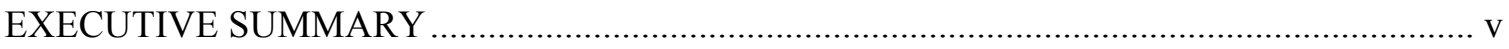

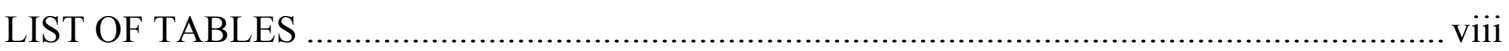

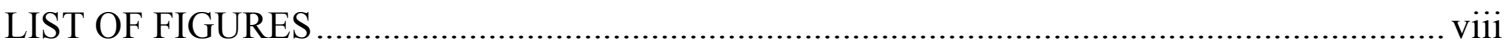

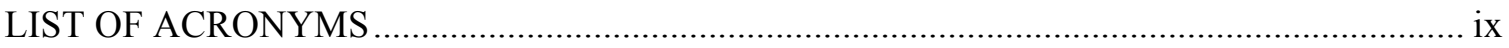

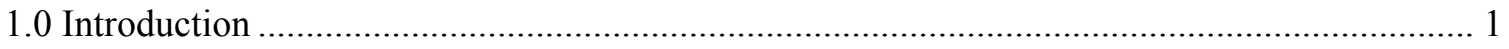

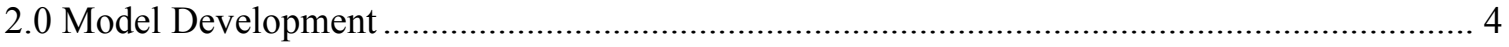

2.1 Development of an Atmospheric Release Model (ARM) in the GoldSim ${ }^{\circledR}$ Programming

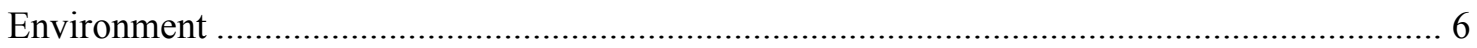

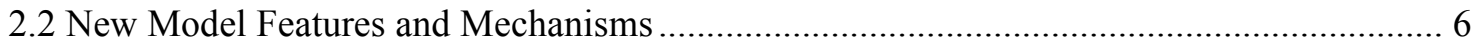

2.2.1 Partitioning of Contaminants across the Air-Water Interface ....................................... 6

2.2.2 Internal Computation of the Effective Air Diffusion Coefficients................................. 7

2.2.3 Imposition of maximum ${ }^{14} \mathrm{CO}_{2}$ vapor concentration in high $\mathrm{pH}$ environments .............. 8

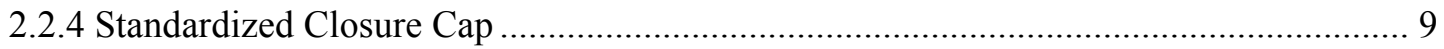

2.2.5 Integration of Individual Models into a Single Model ............................................... 11

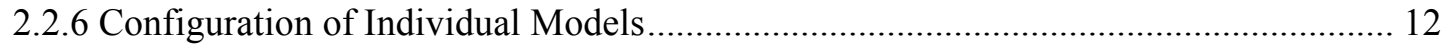

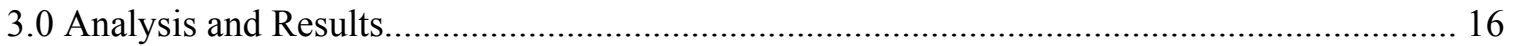

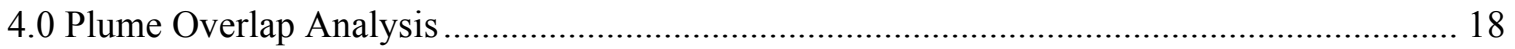

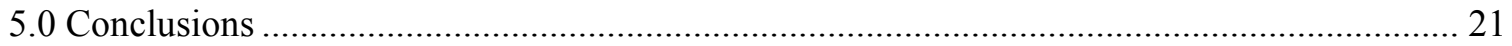

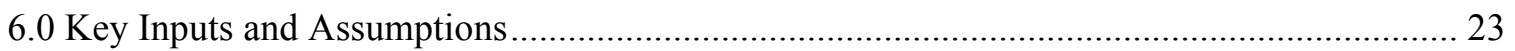

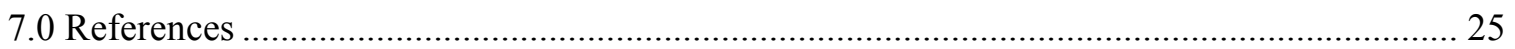

APPENDIX: Atmospheric Pathway Flux at Land Surface and Doses to MEI from Unit Source

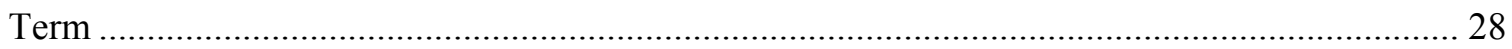




\section{LIST OF TABLES}

Table ES-1. Summary of the PA and New Atmospheric Pathway Disposal Limits for E-Area Facilities

Table 2-1. Radionuclides and Compounds of Interest ….......................................................... 4

Table 2-2. Henry's Law Constants (mole/kg-atm) and Chemical Species Used in this SA (from Denham 2010b)

Table 2-3. Closure Cap Thicknesses, Materials and Properties ................................................... 11

Table 2-4. E-Area Disposal Facilities Materials and Properties................................................. 12

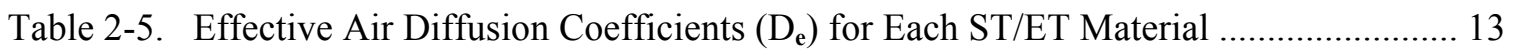

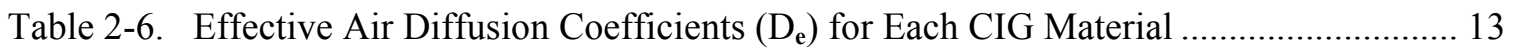

Table 2-7. Effective Air Diffusion Coefficients $\left(D_{\mathbf{e}}\right)$ for Each LAW Vault Material ................. 14

Table 2-8. Effective Air Diffusion Coefficients $\left(D_{\mathbf{e}}\right)$ for Each IL Vault Material........................ 14

Table 2-9. Effective Air Diffusion Coefficients $\left(\mathrm{D}_{\mathbf{e}}\right)$ for Each NRCDA Material ...................... 15

Table 3-1. Peak Contaminant Fluxes and the Time of Peak .................................................. 17

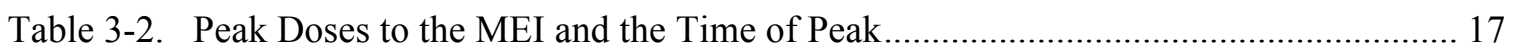

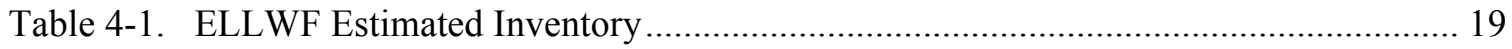

Table 5-1. Updated Atmospheric Pathway Disposal Limits ...................................................... 21

\section{LIST OF FIGURES}

Figure 1-1. Timeline of E-Area Operations and Regulatory Guideline Application...................... 2

Figure 2-1. GoldSim ${ }^{\circledR}$ Model Elements Representing the Standardized Closure Cap ................ 10

Figure 2-2. Illustration of Internal GoldSim ${ }^{\circledR}$ Arrangement of Multiple Transport Models ....... 11

Figure 4-1. Plume Overlap Dose and Dose from Individual Disposal Facilities ........................ 20 


\section{LIST OF ACRONYMS}

$\begin{array}{ll}\text { ARM } & \text { Atmospheric Release Model } \\ \text { CIG } & \text { Components in Grout } \\ \text { CLSM } & \text { Consolidated Low Strength Material } \\ \text { DOE } & \text { Department of Energy } \\ \text { DRF } & \text { Dose Release Factor } \\ \text { ELLWF } & \text { E-Area Low Level Waste Facility } \\ \text { ET } & \text { Engineered Trench } \\ \text { IC } & \text { Institutional Control } \\ \text { ILV } & \text { Intermediate Level Vault } \\ \text { LAWV } & \text { Low Activity Waste Vault } \\ \text { LFRG } & \text { Low Level Waste Disposal Facility Federal Review Group } \\ \text { MEI } & \text { Maximally Exposed Individual } \\ \text { NESHAP } & \text { National Emissions Standards for Hazardous Air Pollutants } \\ \text { NRCDA } & \text { Naval Reactor Component Disposal Area } \\ \text { PDF } & \text { Probability Density Function } \\ \text { POC } & \text { Point of Compliance } \\ \text { SA } & \text { Special Analysis } \\ \text { SRNL } & \text { Savannah River National Laboratory } \\ \text { ST } & \text { Slit Trench } \\ \text { UDQE } & \text { Unreviewed Disposal Question Evaluation } \\ \text { WSRC } & \text { Washington Savannah River Company } \\ & \end{array}$


SRNL-STI-2011-00327

Revision 0

This page is left blank intentionally 
SRNL-STI-2011-00327

Revision 0

\subsection{Introduction}

This Special Analysis (SA) was initiated to address a concern expressed by the Department of Energy's Low Level Waste Disposal Facility Federal Review Group (LFRG) Review Team during their review of the 2008 E-Area Performance Assessment (PA) (WSRC, 2008). Their concern was the potential for overlapping of atmospheric plumes, emanating from the soil surface above SRS LLW disposal facilities within the E-Area, to contribute to the dose received by a member of the public during the Institutional Control (IC) period. The implication of this concern was that the dose to the maximally-exposed individual (MEI) located at the SRS boundary might be underestimated during this time interval. To address this concern a re-analysis of the atmospheric pathway releases from E-Area was required. In the process of developing a new atmospheric release model (ARM) capable of addressing the LFRG plume overlap concern, it became obvious that new and better atmospheric pathway disposal limits should be developed for each of the E-Area disposal facilities using the new ARM. The scope of the SA was therefore expanded to include the generation of these new limits.

The conceptual approach to assessing the atmospheric dose to a member of the public from E-Area LLW disposal facilities is to perform sub-surface simulations of the release of volatile radionuclides from the waste zones through the overlying engineered barriers to determine a flux rate at the land surface. Then, atmospheric dispersion of the radionuclide flux is simulated in an atmospheric transport model (Beres, 1990) to compute air concentrations in the vicinity of the hypothetically exposed individual. A description of the atmospheric transport analysis is found in Lee, 2006. A re-analysis of this portion of the atmospheric pathway releases was not undertaken in this SA, however the Dose Release Factors (DRF's) computed in that study were retained to convert the new surface emanation fluxes (computed with GoldSim) into doses received by the MEI at the appropriate points of compliance (POC). In this way, the doses received by the MEI could be compared to the maximum permissible dose level, defined in DOE Order 435.1, as being $10 \mathrm{mrem} / \mathrm{yr}$ (DOE, 1999).

The initial work conducted in this SA was to develop a new Atmospheric Release Model (ARM) using the GoldSim ${ }^{\circledR}$ program (GTG, 2009). The model simulates the subsurface vapor diffusion of volatile radionuclides as they release from E-Area disposal facility waste zones and migrate to the land surface. In the process of this work, many new features, including several new physical and chemical transport mechanisms, were incorporated into the model. Of all of the improvements, the most important one was to incorporate a mechanism to partition volatile contaminants across the water-air interface within the partially saturated pore space of the engineered and natural materials through which vapor phase transport occurs. The ARM also combines the individual transport models constructed for each E-Area disposal unit into a single model, and was ultimately was used to analyze the LFRG concern regarding the potential for atmospheric plume overlap at the SRS boundary during the IC period.

In the analysis part of this SA the ARM model was utilized to establish new disposal limits for each of the E-Area LLW disposal facilities. In doing so a decision was made to establish the limit on simulated radionuclide releases that occur after Interim Closure is implemented at the end of the E-Area Operations period (or at the beginning of the 100-year IC period), as indicated on the timeline illustrated in Figure 1-1. Final Closure occurs at the end of the 100-yr IC period when the final closure cap is emplaced over the entire E-Area. In this SA, the unit source term of each radionuclide was inserted into the model waste zones for each facility at the end of the 
Operational period, as opposed to the beginning of the Operational period, as was done in the 2008 PA.

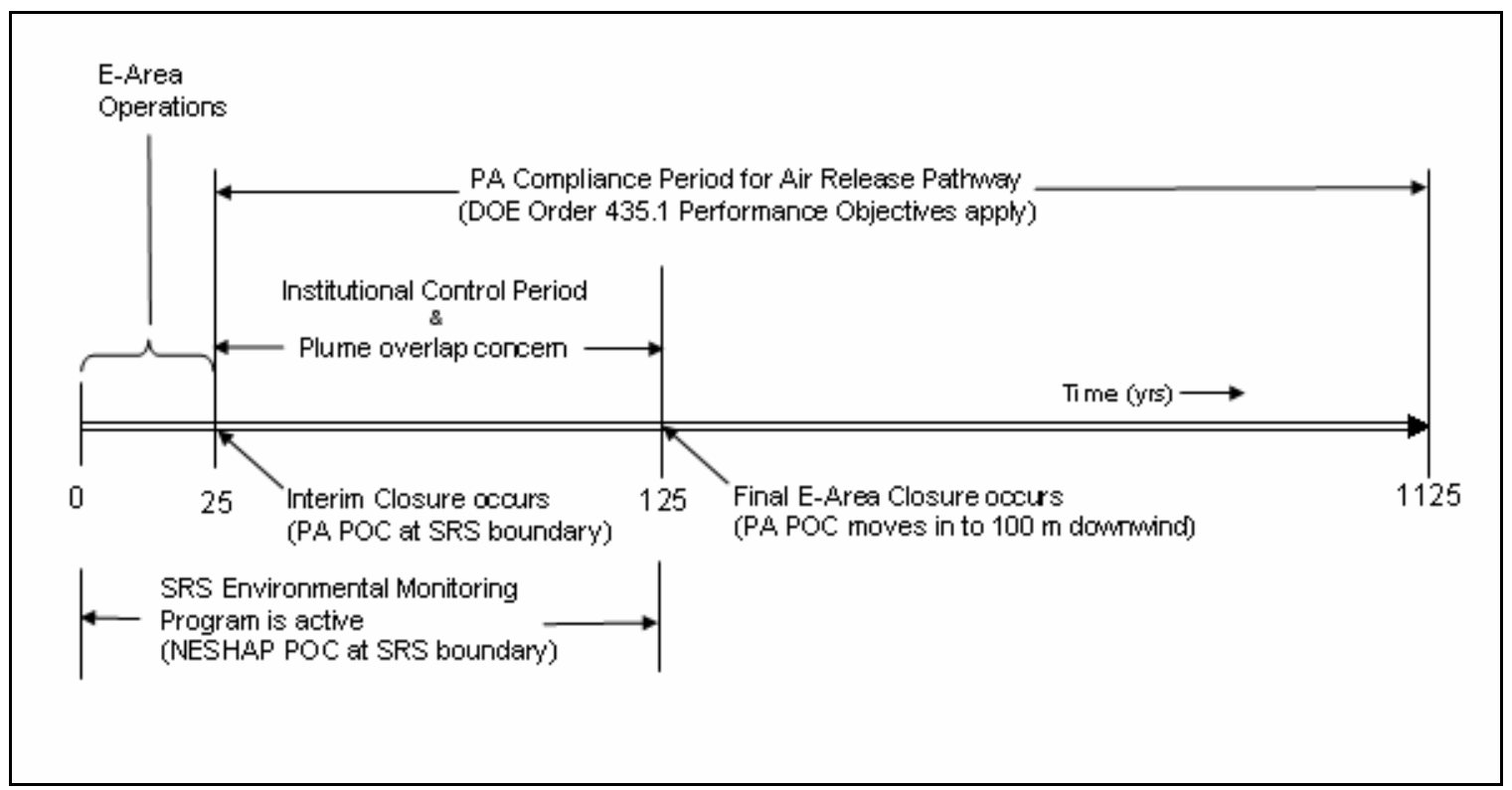

Figure 1-1. Timeline of E-Area Operations and Regulatory Guideline Application

Justification of this decision was based, in part, on re-evaluating the guidance provided within DOE Order 435.1 (DOE, 1999), Radioactive Waste Management. DOE Order 435.1 states that a PA is intended to provide a reasonable expectation that the performance objectives for the longterm protection of the public and environment will not be exceeded "following closure of the facility."

Disposal facilities are not considered to be "closed" during the Operations period hence the Atmospheric pathway performance objective does not apply. However, there is a "reasonable expectation" that the PA atmospheric pathway performance objective is being met during that time-frame as demonstrated through the ongoing SRS Environmental Monitoring Program. This program is administered through the Regulatory Integration and Environmental Services Division at SRS and its results are documented and published annually in the SRS Site Environmental Monitoring Report (SRNS, 2010).

Among other things, the Environmental Monitoring Program is required to demonstrate compliance with the National Emissions Standard for Hazardous Air Pollutants (NESHAP) program requirements (EPA, 2002), which address airborne releases. The performance objective for NESHAP is $10 \mathrm{mrem} / \mathrm{yr}$ assessed at the SRS boundary, which is identical to the DOE 435.1 atmospheric pathway performance objective. The main difference in the two programs is that NESHAP compliance integrates all atmospheric release sources across SRS and not just the diffuse atmospheric releases from E-Area. Even though multiple potential sources are considered, recent history of NESHAP monitoring and evaluation reveals that the estimated dose to the MEI at the SRS boundary has been very small, ranging from 0.04-0.06 mrem/yr since 2002. This represents a fraction of only $0.6 \%$ of the NESHAP and DOE Order 435.1 atmospheric release performance objectives. The SRS Environmental Monitoring Program is expected to remain in place for the duration of the operations period and throughout the IC period. It is reasonable to 
SRNL-STI-2011-00327

Revision 0

assume that the NESHAP compliance assessments will provide an early-warning system if the 10 $\mathrm{mrem} / \mathrm{yr}$ performance objective is being approached. It would also provide the means to identify the cause of any excursions in the estimated dose to the MEI. If any such cause was determined to be associated with E-Area LLW disposal operations the necessary corrective actions could then be implemented.

While the SRS Environmental Monitoring Program will continue to be administered during the 100-yr IC period, it will not be depended upon to provide the "reasonable expectation" of DOE Order 435.1 compliance. The "reasonable expectation" that the PA atmospheric performance objective will not be exceeded during the IC and post-closure periods is provided by simulation of atmospheric releases using the ARM in this SA and basing E-Area disposal limits on those simulated releases.

One point of clarification with regard to the conventions adopted in this SA is that the 25-year period of SRS operations is assumed for all disposal facilities. Strictly speaking, this is not correct for the Slit Trenches, which in reality are expected to have a 30-year period of operations. This assumption does not impact the results of the investigation since the source term is not introduced into any disposal facility until the end of the operations period. The important feature in this SA is that operation periods for all disposal facilities end at the same time, thus requiring the source terms for all disposal facilities to be introduced simultaneously into the ARM.

The development of the ARM model and a detailed description of the new features are presented in Section 2.0 of the SA. The analysis of atmospheric releases is discussed in Section 3.0. The discussion of the atmospheric plume overlap issue is presented in Section 4.0. The conclusions of the SA, including the proposed new atmospheric pathway disposal limits for all E-Area disposal facilities are presented in Section 5.0 while the key inputs and assumptions are presented in Section 6.0. 
SRNL-STI-2011-00327

Revision 0

\subsection{Model Development}

The first step in the re-analysis of the atmospheric pathway was to identify those radionuclides which might potentially become volatile and be available for diffusion through air-filled pores. A screening analysis was conducted prior to the 2008 PA to identify these radionuclides to be more thoroughly analyzed to derive disposal limits for the E-Area disposal facilities based on the atmospheric pathway releases. This study is described in Crapse and Cook (2006) and Denham (2010a). The list of radionuclides requiring a more thorough analysis is: C-14, Cl-36, H-3, I-129, S-35, Sb-124, Sb-125, Se-75, Se-79, Sn-113, Sn-119m, Sn-121, Sn-121m, Sn-123 and Sn-126. A summary of the radionuclides and compounds of interest in this investigation are given in Table 2-1. All of these radionuclides are built into the ARM, in their vapor-state molecular form, and are evaluated each time a simulation is run.

Table 2-1. Radionuclides and Compounds of Interest

\begin{tabular}{|l|c|c|l|c|}
\hline Radionuclide & $\begin{array}{c}\text { Half-Life } \\
\text { (yr) }\end{array}$ & $\begin{array}{c}\text { Atomic } \\
\text { Wt. }\end{array}$ & $\begin{array}{c}\text { Molecular } \\
\text { Form }\end{array}$ & $\begin{array}{c}\text { Molecular } \\
\text { Wt. }\end{array}$ \\
\hline C-14 & $5.73 \mathrm{E}+03$ & 14 & $\mathrm{CO}_{2}$ & 46 \\
\hline Cl-36 & $3.01 \mathrm{E}+05$ & 36 & $\mathrm{HCl}$ & 37 \\
\hline $\mathrm{H}-3$ & $1.23 \mathrm{E}+01$ & 3 & $\mathrm{HTO}$ & 20 \\
\hline $\mathrm{I}-129$ & $1.57 \mathrm{E}+07$ & 129 & $\mathrm{HI}$ & 130 \\
\hline $\mathrm{S}-35$ & $2.39 \mathrm{E}-01$ & 35 & $\mathrm{~S}$ & 35 \\
\hline Sb-124 & $1.65 \mathrm{E}-01$ & 124 & $\mathrm{SbCl}_{3}$ & 229 \\
\hline Sb-125 & $2.76 \mathrm{E}+00$ & 125 & $\mathrm{SbCl}_{3}$ & 230 \\
\hline Se-75 & $3.27 \mathrm{E}-01$ & 75 & $\mathrm{H}_{2} \mathrm{Se}_{2} \mathrm{SeCl}_{4}$ & 77 \\
\hline Se-79 & $2.95 \mathrm{E}+00$ & 79 & $\mathrm{H}_{2} \mathrm{Se} / \mathrm{SeCl}_{4}$ & 81 \\
\hline Sn-113 & $3.15 \mathrm{E}-01$ & 113 & $\mathrm{SnCl}_{4}$ & 268 \\
\hline Sn-119m & $8.02 \mathrm{E}-01$ & 119 & $\mathrm{SnCl}_{4}$ & 259 \\
\hline Sn-121 & $3.09 \mathrm{E}-03$ & 121 & $\mathrm{SnCl}_{4}$ & 261 \\
\hline Sn-121m & $4.41 \mathrm{E}+01$ & 121 & $\mathrm{SnCl}_{4}$ & 261 \\
\hline Sn-123 & $3.55 \mathrm{E}-01$ & 123 & $\mathrm{SnCl}_{4}$ & 263 \\
\hline Sn-126 & $2.30 \mathrm{E}+05$ & 126 & $\mathrm{SnCl}_{4}$ & 266 \\
\hline
\end{tabular}

In evaluating atmospheric pathway releases from disposal facilities to the environment, the basic conceptual model for contaminant transport proceeds exclusively by diffusion within the air-filled pore spaces of the disposal facility waste zones, engineered barriers, and closure caps.

The rate of diffusion is

$$
\vec{F}=-D p \vec{\nabla} C
$$

Where:

$$
\begin{aligned}
& \vec{F}=\text { flux }\left(\mathrm{Bq} \mathrm{m} \mathrm{m}^{-2} \mathrm{~s}^{-1}\right) \\
& D=\operatorname{diffusion} \text { coefficient }\left(\mathrm{m}^{2} \mathrm{~s}^{-1}\right) \\
& p=\text { total porosity } \\
& C=\text { Concentration }\left(\mathrm{Bq} \mathrm{m}^{-3}\right)
\end{aligned}
$$


The conceptual model implemented in the ARM is a 1-D column of computational elements, having no-flow boundaries on sides and bottom, so as to divert all contaminant fluxes to the land surface. These boundary conditions are conservative in that, in reality, diffusion may also proceed laterally and downward in the subsurface. The materials contained in these elements represent those of waste zone, engineered barriers, sand fill and closure cap of the individual disposal facilities. Configurations conforming to the anticipated closure designs of each facility type (e.g., dimensions of waste zones and engineered barriers) were adhered to, as was the general occurrence and timings of events encompassed in the loading and closure of the facilities in EArea. Material properties associated with each disposal facility, including porosity, particle density, residual water saturations, etc. identified in the 2008 PA (WSRC, 2008) were largely adhered to in this SA, except where better estimates could be obtained.

The radionuclides evaluated in this SA exist in the gaseous state, consequently air is considered to be the medium in which transport occurs. The flow field is assumed to be isobaric and isothermal. The impact of naturally occurring fluctuations in atmospheric pressure at the land surface, that could induce small pulses of air movement into and out of the shallow soil profile over relatively short periods of time are assumed to have zero net effect when averaged over longer periods of time. Therefore, for the relatively long periods of time evaluated in this SA, air diffusion was the only transport mechanism simulated in the model and advective transport was assumed to be negligible.

While some fraction of the gaseous elements and compounds dissolve in residual pore water, the ability of water-dissolved elements and compounds to diffuse through water-filled pores is negligible when compared to the ability of the same elements and compounds to diffuse as gasses in the vapor-filled pore space. This assertion is based on the recognition that diffusion coefficients for elements and compounds are approximately four orders of magnitude lower for water as compared to air coefficients for the same elements or compound. Considering this contrast, and the fact that water is conservatively assumed to be stationary in this model (when in fact it is moving slowly downward), water diffusion is not considered in the ARM.

The performance objective that is specifically evaluated in this SA is the $10 \mathrm{mrem} / \mathrm{yr}$ exposure limit to a member of the public. The point of compliance (POC) where this objective must be evaluated is at the SRS boundary during the IC and at the $100 \mathrm{~m}$ downwind location during the post-closure period. In keeping with this guidance, the waste was assumed to be fully loaded within each disposal facility at the beginning of the IC period and allowed to diffuse through the subsurface from that point onward, until the end of the post-closure period.

A summary of the main assumptions associated with development of the ARM includes:

- No-flux boundaries on the sides and base of the 1-D stack of GoldSim ${ }^{\circledR}$ elements. This is conservative because it forces all vapor-phase diffusion to proceed upward to the land surface when, in actuality, some diffusion proceeds laterally and downward.

- The domain is isothermal and isobaric. Short-term oscillations in temperature and pressure are thought to have a long-term net zero effect.

- Waste is not introduced into the model of each disposal facility until operational closure is achieved. This is conservative in that any radioactive decay and diffusive air releases that may have occurred during the operations period is not accounted for, thus the source term is slightly larger than in actuality. 
- All E-Area disposal facilities are simulated in the ARM such that operational closure is reached simultaneously. This assumption is conservative mainly for the assessment of plume overlap during the IC period, tending to cause surface flux peaks to occur simultaneously.

\subsection{Development of an Atmospheric Release Model (ARM) in the GoldSim ${ }^{\circledR}$ Programming Environment}

The computational model utilized to simulate subsurface transport of volatile radionuclides in this SA was developed in the GoldSim ${ }^{\circledR}$ Version. 10.5 programming environment. GoldSim ${ }^{\circledR}$ is an analytical contaminant transport code. When the flow field is specified, it has the ability to compute both advective and diffusive transport of contaminant species; however it lacks the ability to compute advective flow. The code is normally implemented using a 1D arrangement of computational elements to approximate a flow domain although 2D meshes can be configured. Radioactive decay and chemical retardation within a flow field are easily implemented and multiple contaminants are simulated simultaneously. One of the main functional features of the code is its ability to perform multiple realizations for stochastic analysis and flexibility in selection of probability density functions (PDF's) for uncertain parameters.

\section{$\underline{2.2}$ New Model Features and Mechanisms}

The ARM is a much more robust and flexible model than has been previously used for air dose modeling at the SRS. An effort was made to incorporate a more accurate representation of physical features and properties of each facility, honoring the configuration of the waste zones, engineered features and overlying closure cap layers. Many parameters were built into the ARM using GoldSim ${ }^{\mathbb{R},}$ s probabilistic input elements, which are not used in this SA other than to select the designated central value for deterministic realizations, but will be easy to invoke in GoldSim $^{\circledR}$, s probabilistic mode at the appropriate time to perform uncertainty and sensitivity analyses. In addition to this, the incorporation of the mechanism to equilibrate the concentration of contaminants across the air-water interface according to Henry's Law constants for the elements considered in this SA allow for more accurate simulations of contaminant flux at the land surface. Another feature, the mechanism to automatically compute effective diffusion coefficients for each material, by radionuclide, during each simulation introduces a flexibility that enables the user to easily investigate the impact of varying selected parameter values (e.g., porosity and residual saturation) on the result. Additionally, certain parameters were structured with "global" connections where appropriate, making adjustments to these parameters much easier to simultaneously incorporate for all disposal facilities. Finally, the combining of all disposal facility models into a single E-Area model provides the ability to evaluate the combined impact of multiple facilities on a single MEI, which is ultimately how the LFRG plume overlap concern is addressed. Expanded discussions of these features are provided below.

\subsubsection{Partitioning of Contaminants across the Air-Water Interface}

One of the principal improvements to the current atmospheric pathway model is the incorporation of a mechanism to evaluate the partitioning of contaminants across the air-water interface within the pore space of different materials that are partially filled with an air-water mixture. This 
mechanism utilizes constants derived from Henry's Law for calculation of the partitioning in both cementitious and non-cementitious materials.

Henry's Law describes the partitioning of species between the aqueous phase and the gas phase. A recent study (Denham 2010b) gives the Henry's Law constants for relevant radionuclides under a variety of conditions. Conditions representing soil ( $\mathrm{pH} 5.4$, Eh 0.37 ) and aged concrete ( $\mathrm{pH} 8.23$ Eh 0.73 ) were used in this SA as new models were constructed for each E-Area disposal facility. The analysis used to derive the Henry's Law constants also gave the chemical form of each radionuclide that would be most stable in the vapor phase under each condition. This information is shown in Table 2-2.

Table 2-2. Henry's Law Constants (mole/kg-atm) and Chemical Species Used in this SA (from Denham 2010b)

\begin{tabular}{|c|c|c|c|c|c|c|c|}
\hline & $\mathbf{C}$ & $\mathbf{C l}$ & $\mathbf{H}$ & $\mathbf{I}$ & $\mathbf{S b}$ & Se & Sn \\
\hline \multirow{2}{*}{ Soil } & $3.8 \mathrm{E}-2$ & $5.2 \mathrm{E} 11$ & $2.1 \mathrm{E} 3$ & $6.3 \mathrm{E} 14$ & $6.9 \mathrm{E} 32$ & $2.8 \mathrm{E} 25$ & $9.6 \mathrm{E} 53$ \\
& $\left(\mathrm{CO}_{2}\right)$ & $(\mathrm{HCl})$ & $\left(\mathrm{H}_{2} \mathrm{O}\right)$ & $(\mathrm{HI})$ & $\left(\mathrm{SbCl}_{3}\right)$ & $\left(\mathrm{H}_{2} \mathrm{Se}\right)$ & $\left(\mathrm{SnCl}_{4}\right)$ \\
\hline $\begin{array}{c}\text { Aged } \\
\text { Concrete }\end{array}$ & $2.8 \mathrm{E} 0$ & $3.6 \mathrm{E} 14$ & $2.1 \mathrm{E} 3$ & $1.3 \mathrm{E} 29$ & $4.9 \mathrm{E} 38$ & $3.8 \mathrm{E} 87$ & $6.1 \mathrm{E} 61$ \\
$\left(\mathrm{CO}_{2}\right)$ & $(\mathrm{HCl})$ & $\left(\mathrm{H}_{2} \mathrm{O}\right)$ & $\left(\mathrm{I}_{2}\right)$ & $\left(\mathrm{SbCl}_{3}\right)$ & $\left(\mathrm{SeCl}_{4}\right)$ & $\left(\mathrm{SnCl}_{4}\right)$ \\
\hline
\end{tabular}

The ARM requires the Henry's Law constants as the dimensionless ratio:

$$
\frac{\text { quantity in vapor phase }}{\text { quantity in aqueous phase }}
$$

The conversion factor for this is 4.1E-02 (kg-atm)/mole (Sandler 1997). The values presented in this table were implemented within the new ARM model as partitioning coefficients for individual radionuclides within the different material zones.

\subsubsection{Internal Computation of the Effective Air Diffusion Coefficients}

The effective diffusion coefficients $\left(\mathrm{D}_{\mathrm{e}}\right)$ for volatile radionuclides and molecules within various porous media were built directly into the ARM. The advantage of performing the calculation internally within the transport model is that it readily enables the evaluation of the sensitivity of the model results to the values assumed for porosity and residual water saturation. Furthermore, transient water saturations of materials based on computations external to the ARM can easily be incorporated by simply adjusting that property for the selected material at the appropriate times.

The initial step is to compute the $\mathrm{D}_{\mathrm{e}}$ for $\mathrm{Rn}-222$ as a function of the porosity and moisture saturation as a reference case for the other volatile radionuclides. The equations to perform this computation are defined in Rogers and Nielsen, 1991. Two separate equations, identified in that paper, are built into the ARM and are listed below. The user may select either one or the other; however, Equation 2 is based on the analysis of many more samples and is regarded as more accurately representing the complex relationship between $\mathrm{D}_{\mathrm{c}}$, porosity and pore volume fraction of water. 


$$
D_{c}=D_{0} \times A_{0} \times p_{a}^{b_{0}}
$$

where:

$D_{o}=$ diffusion coefficient in air $\quad\left(\mathrm{L}^{2} / \mathrm{t}\right)$

$A_{o}, b_{o}=$ empirical functions of porosity or constants

$p_{a}=$ air-filled porosity $=p(1-S)$

$S=$ pore volume fraction of water or residual saturation

In Rogers and Nielson (1991), the constants $A_{o}$ and $b_{o}$ are defined as 0.74 and 2.2 for Rn-222, respectively. Also in this research paper, an improved equation relating the "complete" diffusion coefficient, $D_{c}$ (synonymous with "effective" diffusion coefficient, $D_{e}$ ) to estimates of total porosity and volume fraction of water saturation for various porous media is presented. This is:

$$
D_{c}=D_{0} p \times \exp \left[-6 S p-6 S^{14 p}\right]
$$

where:

$D_{o}=$ diffusion coefficient in air

$p=$ total porosity

$S=$ volume fraction of water saturation

While implementing these equations in GoldSim ${ }^{\circledR}$, a minor issue was discovered in that all isotopes of an element are assumed to have the same diffusion coefficient. While this is not the case for an air diffusion model, the affect in the ARM is quite small, and is proportional to the difference in atomic weights of the isotopes. Therefore, this effect could be ignored.

Once the $D_{e}$ of $R n-222$ is computed for a particular material, with unique porosity and a specified long-term residual saturation, the $\mathrm{D}_{\mathrm{e}}$ of the other volatile radionuclides or molecular compounds evaluated in this SA were computed using the relationship described by Graham's Law:

$$
D_{e}=D_{e}^{\prime} \sqrt{\frac{M W T^{\prime}}{M W T}}
$$

Where:

$D_{e}=$ the diffusion coefficient of the radionuclide of interest $\left(\mathrm{m}^{2} / \mathrm{yr}\right)$

$D_{e}^{\prime}=$ the diffusion coefficient of the reference radionuclide $(\mathrm{Rn}-222)\left(\mathrm{m}^{2} / \mathrm{yr}\right)$

$M W T^{\prime}=$ the atomic weight of the reference radionuclide (Rn-222)

$M W T=$ the molecular weight of the vapor form of the radionuclide of interest

\subsubsection{Imposition of maximum ${ }^{14} \mathrm{CO}_{2}$ vapor concentration in high $\mathrm{pH}$ environments}

Development of the ARM included the imposition of a constant concentration for ${ }^{14} \mathrm{CO}_{2}$ in the vapor-filled pore spaces of cementitious materials. The basis for this is documented in Kaplan, 
2005 where the thermodynamic equations describing the equilibration of a C-14 waste source with high $\mathrm{pH}$ water were evaluated. The key processes evaluated in this study included: (1) the equilibration of ${ }^{12} \mathrm{CO}_{3}{ }^{2-}{ }_{\text {(aq) }}$ and ${ }^{14} \mathrm{CO}_{3}{ }^{2-}$ (aq) with cementitious pore water, and (2) volatilization of ${ }^{12} \mathrm{CO}_{2(\mathrm{~g})}$ and ${ }^{14} \mathrm{CO}_{2(\mathrm{~g})}$ from the cement-equilibrated ${ }^{12} \mathrm{CO}_{3}{ }^{2-}$ (aq) and ${ }^{14} \mathrm{CO}_{3}{ }^{2-}$ (aq). The study concluded that $\mathrm{C}-14$ concentrations is the gaseous state would not exceed $1.9 \mathrm{E}-07 \mathrm{Ci} / \mathrm{m}^{3}$.

Conceptually, the cementitious material provides a very strong sorbent for the ${ }^{14} \mathrm{CO}_{(\mathrm{g})}^{2}$. In fact, industries that generate 1000's of times greater amounts of C-14 than anticipated for the ILV, such as the Ontario Hydro's Reactors (Dayal et al. 1989; Dayal and Reardon 1992), dispose of C14 bearing resins along with concrete slabs; the concrete slabs are referred to as "C-14 getters." Consequently, little ${ }^{14} \mathrm{CO}_{2(\mathrm{~g})}$ is expected to be released from E-Area facilities containing cementitious material. The use of this concept to simulate releases of ${ }^{14} \mathrm{CO}_{2}$ from E-Area waste disposal facilities is also reinforced by widespread attention currently being directed to the use of concrete as a means to sequester atmospheric $\mathrm{CO}_{2}$.

The concept was previously employed in a SA to evaluate the atmospheric releases of ${ }^{14} \mathrm{CO}_{2}$ from the ILV (Hiergesell, et. al. 2005). This SA evaluated the disposal of up to 52 deionizer vessels loaded with resins containing C-14, and utilized the concentration limit from Kaplan, 2005 to evaluate atmospheric release of C-14.

\subsubsection{Standardized Closure Cap}

A standardized closure cap model, conforming to the design of the anticipated final closure cap that will be placed over all of the E-Area facilities at the end of Institutional Control, was developed and implemented within the ARM for each E-Area disposal facility. The features of the final closure cap are described in the Closure Plan for the E-Area Low-Level Waste Facility (SRNL 2009) in Section 4.4. One particular feature that is described in the closure cap is the Erosion Barrier (EB). This layer consists of granite cobbles with a fill material added to the spaces between the cobbles. A decision has not been made as to what material will be used for the fill, however several possibilities are mentioned. This SA assumes that a material with porosity of 0.328 and a long-term residual saturation of 0.825 will be used to fill the interstitial spaces between granite cobbles. The EB porosity, bulk density and residual saturation of the EB were calculated based on this assumption. Figure 2-1 indicates the GoldSim ${ }^{\circledR}$ closure cap mixing cell arrangement within the model and is clearly labeled to indicate the material layers represented. The arrows in the figure indicate diffusive links exist between adjacent cells.

Table 2-3 indicates the specific layer thicknesses, particle densities, porosities and expected longterm residual saturations associated with each layer. Note that the Geotextile materials are represented with the properties of the layer directly beneath them, since the actual properties that influence diffusive transport of the radionuclides are not known at this time. 
SRNL-STI-2011-00327

Revision 0

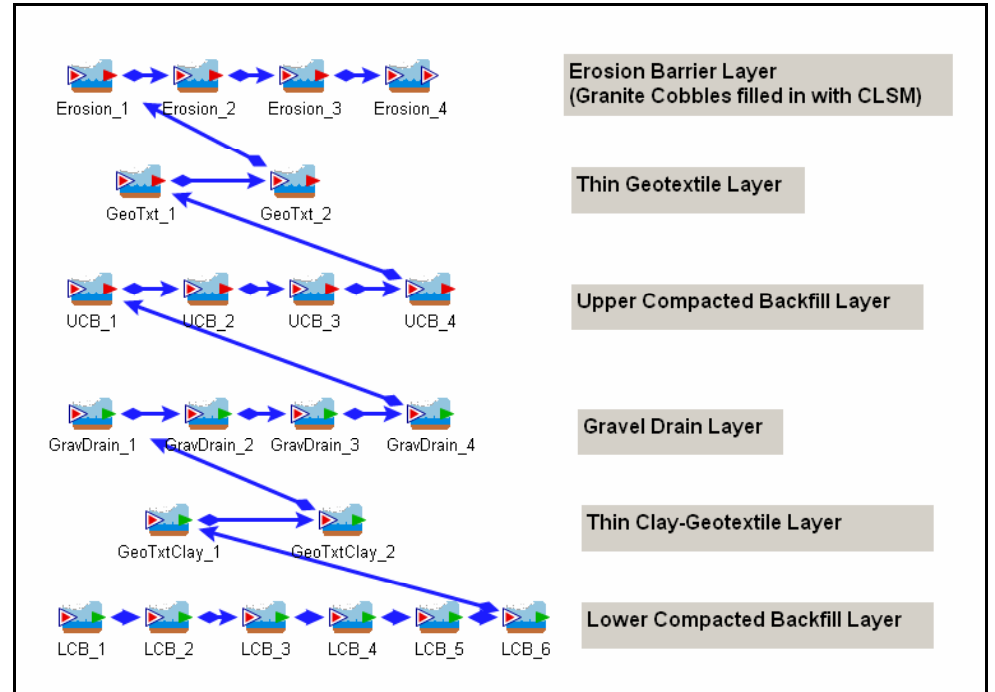

Figure 2-1. GoldSim ${ }^{\circledR}$ Model Elements Representing the Standardized Closure Cap

The material properties utilized to characterize the individual layers of the closure cap conform closely to the values for the listed materials that were established and utilized within the 2008 PA. The properties selected for the erosion barrier require additional clarification. In this investigation, the granite cobbles themselves are assumed to be solid and not to possess any porosity. The cobbles collectively, however, are assumed to have a porosity of 0.27 . Hence the Erosion Barrier total porosity is calculated to be the product of the cobble/boulder inter-solid space $(0.27)$ and the porosity of the fill material $(0.328)$, which produces the 0.088 number indicated in Table 2-3. 
Table 2-3. Closure Cap Thicknesses, Materials and Properties

\begin{tabular}{|l|c|c|c|c|}
\hline \multicolumn{1}{|c|}{ Layer } & $\begin{array}{c}\text { Thickness } \\
\text { (ft) }\end{array}$ & $\begin{array}{c}\text { Particle } \\
\text { Density } \\
\left(\mathbf{g} / \mathbf{c m}^{\mathbf{3}}\right)\end{array}$ & Porosity & $\begin{array}{c}\text { Residual } \\
\text { Water } \\
\text { Saturation }\end{array}$ \\
\hline Erosion Barrier & 1 & 2.67 & 0.088 & 0.825 \\
\hline Geotextile & 0.1667 & 2.63 & 0.35 & 0.7 \\
\hline Upper Compacted Backfill & 1 & 2.63 & 0.35 & 0.7 \\
\hline Gravel Drain & 1 & 2.6 & 0.3 & 0.525 \\
\hline Clay-Geotextile & 0.1667 & 2.65 & 0.35 & 0.7 \\
\hline Lower Compacted Backfill & $2^{1}$ & 2.65 & 0.35 & 0.7 \\
\hline
\end{tabular}

Note: ${ }^{1}$ Thickness for ST/ET, LAW Vault and NRCDA are 40 in.

\subsubsection{Integration of Individual Models into a Single Model}

While the previous atmospheric release simulations performed at SRNL were conducted for each E-Area disposal facility as separate models, the GoldSim ${ }^{\circledR}$ programming environment has the advantage of allowing each separate facility to be included within the single GoldSim ${ }^{\circledR}$ (ARM) model. This allows for the efficient arrangement of global items into directories that are accessed by all individual facility models. Each ARM realization produces results for all facilities.

Computation time is virtually unaffected by this integration. The combining of multiple disposal facilities into a single model enables the relatively straight-forward evaluation of the plumeoverlap issue, which is addressed later. Figure 2-2 illustrates the arrangement of individual folders (or "Containers" in GoldSim ${ }^{\circledR}$ terminology) within which the separate transport zones, unique characteristics and results are contained. The right-hand side of the figure illustrates the GoldSim $^{\circledR}$ capability for building in graphics and explanations to document the model.

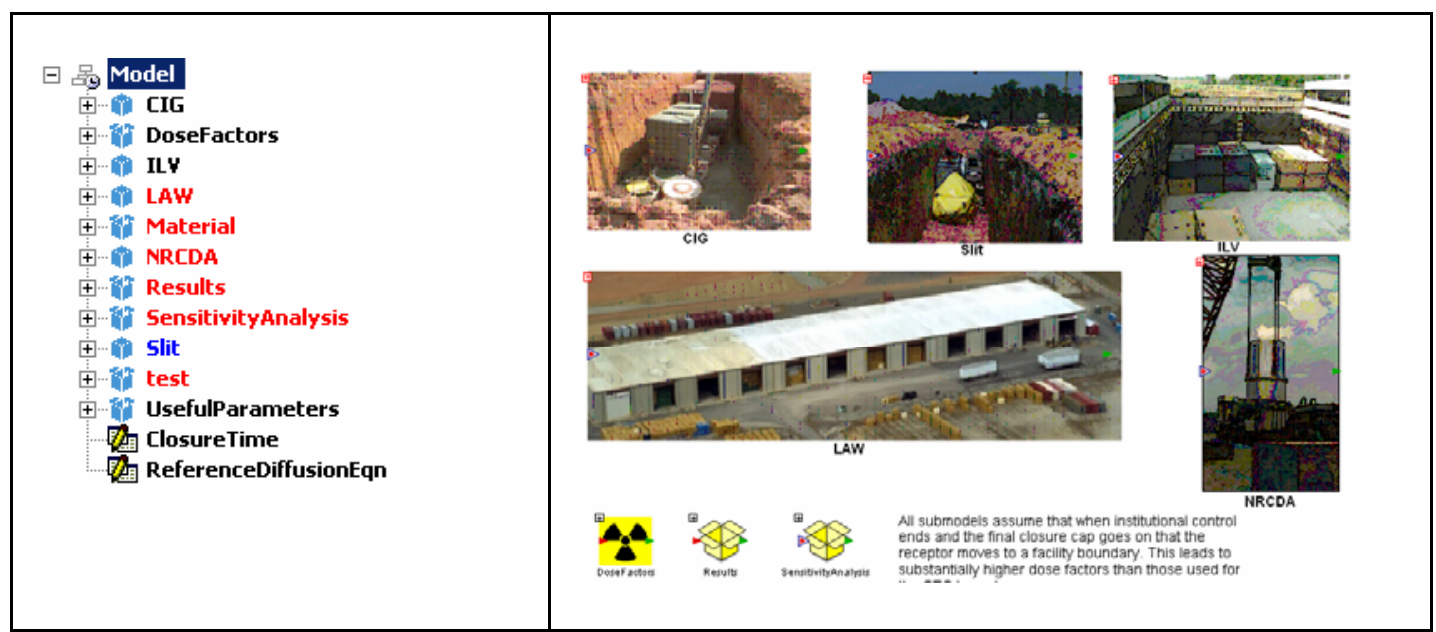

Figure 2-2. Illustration of Internal GoldSim ${ }^{\circledR}$ Arrangement of Multiple Transport Models 
SRNL-STI-2011-00327

Revision 0

\subsubsection{Configuration of Individual Models}

For each individual disposal facility built into the ARM, the configuration consists of a 1-D stack of model cells that represent the waste emplacement zone, engineered barriers and closure cap of each E-Area disposal facility. The extent of the vertical stack of cells was from the base of the waste zone to the top of the Erosion Barrier, which is in the overlying closure cap and is assumed to be the land surface from which contaminant fluxes emanate during the post-closure period. As described in the conceptual model, no-flow boundaries were prescribed on the sides and bottoms of each vertical stack. The opening and closing of diffusive links between various cells are synchronized to conform to the operations and closure sequences for each facility.

The pertinent information regarding specific materials zones, their thicknesses and material properties, as well as the specific $\mathrm{D}_{\mathbf{e}}$ computed in the model for each radionuclide, by material zone is presented in Tables 2-4 through 2-9 for the Slit and Engineered Trenches (ST/ET), Component in Grout (CIG) Trenches, Low Activity Waste Vault (LAWV) Vaults, Intermediate Level (IL) Vaults, and Naval Reactor Component Disposal Areas (NRCDA's), respectively.

Table 2-4. E-Area Disposal Facilities Materials and Properties

\begin{tabular}{|c|c|c|c|c|}
\hline & $\begin{array}{c}\text { Thickness } \\
\text { (ft) }\end{array}$ & $\begin{array}{l}\text { Particle } \\
\text { Density } \\
\left(\mathrm{g} / \mathrm{cm}^{3}\right) \\
\end{array}$ & Porosity & $\begin{array}{c}\text { Residual } \\
\text { Water } \\
\text { Saturation } \\
\end{array}$ \\
\hline \multicolumn{5}{|c|}{ Slit and Engineered Trenches } \\
\hline Clean fill & 4 & 2.65 & 0.46 & 0.826 \\
\hline Compacted Fill $^{1}$ & 12 & 2.65 & 0.46 & 0.826 \\
\hline Upper Waste Zone & 8 & 2.65 & 0.46 & 0.826 \\
\hline Lower Waste Zone & 8 & 2.65 & 0.46 & 0.826 \\
\hline \multicolumn{5}{|c|}{ Component in Grout Trenches } \\
\hline Clean Sand & 4 & 2.65 & 0.46 & 0.826 \\
\hline Concrete Slab & 1 & 2.65 & 0.46 & 0.826 \\
\hline CIG_Waste & 15 & 2.65 & 0.5 & 0.826 \\
\hline \multicolumn{5}{|c|}{ Low Activity Waste Vault } \\
\hline Concrete Roof & 1.33 & 2.59 & 0.184 & \\
\hline LAWV Waste & 24.5 & 2.65 & 0.5 & \\
\hline \multicolumn{5}{|c|}{ Intermediate Level Vault } \\
\hline Concrete Roof & 2 & 2.59 & 0.184 & 0.815 \\
\hline CLSM & 0.25 & 2.65 & 0.324 & 0.823 \\
\hline ILV Waste Zone & 27 & 2.32 & 0.74 & 0.1 \\
\hline \multicolumn{5}{|c|}{ NRCDA } \\
\hline Clean Sand & 4 & 2.65 & 0.46 & 0.825 \\
\hline Waste Zone & 17 & 1.65 & 0.2 & 0.2 \\
\hline
\end{tabular}

Note: ${ }^{1}$ This layer is emplaced after institutional control. Prior to this emplacement, contaminants diffuse directly from the Upper Waste Zone into the Clean fill. 
Table 2-5. Effective Air Diffusion Coefficients $\left(D_{e}\right)$ for Each ST/ET Material

\begin{tabular}{|c|c|c|c|c|}
\hline Radionuclide & $\begin{array}{l}\mathrm{D}_{\mathrm{e}}\left(\mathrm{m}^{2} / \mathrm{yr}\right) \\
\text { Lower WZ }\end{array}$ & $\begin{array}{l}D_{\mathrm{e}}\left(\mathrm{m}^{2} / \mathrm{yr}\right)^{1} \\
\text { Upper WZ }\end{array}$ & $\begin{array}{c}\mathrm{D}_{\mathrm{e}}\left(\mathrm{m}^{2} / \mathrm{yr}\right)^{2} \\
\text { Compacted Soil }\end{array}$ & $\begin{array}{l}\mathrm{D}_{\mathrm{e}}\left(\mathrm{m}^{2} / \mathrm{yr}\right) \\
\text { Clean Soil }\end{array}$ \\
\hline $\mathrm{C}-14$ & 2.83 & 2.83 & 2.83 & 2.83 \\
\hline Cl-36 & 6.22 & 6.22 & 6.22 & 6.22 \\
\hline H-3 & 6.93 & 6.93 & 6.93 & 6.93 \\
\hline I-129 & 9.43 & 9.43 & 9.43 & 9.43 \\
\hline S-35 & 3.70 & 3.70 & 3.70 & 3.70 \\
\hline Sb-124 & 7.13 & 7.13 & 7.13 & 7.13 \\
\hline Sb-125 & 2.79 & 2.79 & 2.79 & 2.79 \\
\hline Se-75 & 2.78 & 2.78 & 2.78 & 2.78 \\
\hline Se-79 & 4.81 & 4.81 & 4.81 & 4.81 \\
\hline Sn-113 & 4.68 & 4.68 & 4.68 & 4.68 \\
\hline Sn-119m & 2.65 & 2.65 & 2.65 & 2.65 \\
\hline Sn-121 & 2.62 & 2.62 & 2.62 & 2.62 \\
\hline Sn-121m & 2.61 & 2.61 & 2.61 & 2.61 \\
\hline Sn-123 & 2.61 & 2.61 & 2.61 & 2.61 \\
\hline Sn-126 & 2.60 & 2.60 & 2.60 & 2.60 \\
\hline
\end{tabular}

Notes: ${ }^{1}$ zero (0) after compaction; ${ }^{2}$ exists after compaction

Table 2-6. Effective Air Diffusion Coefficients $\left(D_{\mathrm{e}}\right)$ for Each CIG Material

\begin{tabular}{|c|c|c|c|}
\hline Radionuclide & $\begin{array}{c}\mathbf{D}_{\mathbf{e}}\left(\mathbf{m}^{\mathbf{2}} / \mathbf{y r}\right) \\
\text { CIG Waste }\end{array}$ & $\begin{array}{c}\mathbf{D}_{\mathbf{e}}\left(\mathbf{m}^{\mathbf{2}} / \mathbf{y r}\right) \\
\text { Concrete Roof }\end{array}$ & $\begin{array}{c}\mathbf{D}_{\mathbf{e}}\left(\mathbf{m}^{\mathbf{2}} / \mathbf{y r}\right) \\
\text { Clean Soil }\end{array}$ \\
\hline $\mathrm{C}-14$ & 282.47 & 2.20 & 6.22 \\
\hline $\mathrm{Cl}-36$ & 314.96 & 2.45 & 6.93 \\
\hline $\mathrm{H}-3$ & 428.39 & 3.33 & 9.43 \\
\hline $\mathrm{I}-129$ & 168.03 & 1.31 & 3.70 \\
\hline $\mathrm{S}-35$ & 323.83 & 2.52 & 7.13 \\
\hline $\mathrm{Sb}-124$ & 126.6 & 0.98 & 2.79 \\
\hline $\mathrm{Sb}-125$ & 126.33 & 0.98 & 2.78 \\
\hline $\mathrm{Se}-75$ & 218.33 & 1.70 & 4.80 \\
\hline $\mathrm{Se}-79$ & 212.87 & 1.70 & 4.68 \\
\hline $\mathrm{Sn}-113$ & 120.45 & 0.94 & 2.65 \\
\hline $\mathrm{Sn}-119 \mathrm{~m}$ & 119.04 & 0.94 & 2.62 \\
\hline $\mathrm{Sn}-121$ & 118.59 & 0.94 & 2.61 \\
\hline $\mathrm{Sn}-121 \mathrm{~m}$ & 118.59 & 0.94 & 2.61 \\
\hline $\mathrm{Sn}-123$ & 118.13 & 0.94 & 2.60 \\
\hline $\mathrm{Sn}-126$ & 117.47 & 0.94 & 2.59 \\
\hline
\end{tabular}


Table 2-7. Effective Air Diffusion Coefficients $\left(D_{e}\right)$ for Each LAW Vault Material

\begin{tabular}{|c|c|c|}
\hline Radionuclide & $\begin{array}{c}\mathbf{D}_{\mathbf{e}}\left(\mathbf{m}^{\mathbf{2}} / \mathbf{y r}\right) \\
\text { LAW Waste }\end{array}$ & $\begin{array}{c}\mathbf{D}_{\mathbf{e}}\left(\mathbf{m}^{\mathbf{2}} / \mathbf{y r}\right) \\
\text { Concrete Roof }\end{array}$ \\
\hline $\mathrm{C}-14$ & 282.47 & 2.20 \\
\hline $\mathrm{Cl}-36$ & 314.96 & 2.45 \\
\hline $\mathrm{H}-3$ & 428.39 & 3.33 \\
\hline $\mathrm{I}-129$ & 168.03 & 1.31 \\
\hline $\mathrm{S}-35$ & 323.83 & 2.52 \\
\hline $\mathrm{Sb}-124$ & 126.6 & 0.98 \\
\hline $\mathrm{Sb}-125$ & 126.33 & 0.98 \\
\hline $\mathrm{Se}-75$ & 218.33 & 1.70 \\
\hline $\mathrm{Se}-79$ & 212.87 & 1.70 \\
\hline $\mathrm{Sn}-113$ & 120.45 & 0.94 \\
\hline $\mathrm{Sn}-119 \mathrm{~m}$ & 119.04 & 0.94 \\
\hline $\mathrm{Sn}-121$ & 118.59 & 0.94 \\
\hline $\mathrm{Sn}-121 \mathrm{~m}$ & 118.59 & 0.94 \\
\hline $\mathrm{Sn}-123$ & 118.13 & 0.94 \\
\hline $\mathrm{Sn}-126$ & 117.47 & 0.94 \\
\hline
\end{tabular}

Table 2-8. Effective Air Diffusion Coefficients $\left(D_{e}\right)$ for Each IL Vault Material

\begin{tabular}{|l|c|c|c|}
\hline Radionuclide & $\begin{array}{c}\mathbf{D}_{\mathbf{e}}\left(\mathbf{m}^{\mathbf{2}} / \mathbf{y r}\right) \\
\text { ILV Waste }\end{array}$ & $\begin{array}{c}\mathbf{D}_{\mathbf{e}}\left(\mathbf{m}^{\mathbf{2}} \mathbf{y r}\right) \\
\text { CLSM }\end{array}$ & $\begin{array}{c}\mathbf{D}_{\mathbf{e}}\left(\mathbf{m}^{\mathbf{2}} / \mathbf{y r}\right)^{\mathbf{1}} \\
\text { Concrete Roof }\end{array}$ \\
\hline $\mathrm{C}-14$ & 282.47 & 4.25 & 2.20 \\
\hline $\mathrm{Cl}-36$ & 314.96 & 4.74 & 2.45 \\
\hline $\mathrm{H}-3$ & 428.39 & 6.44 & 3.33 \\
\hline $\mathrm{I}-129$ & 168.03 & 2.53 & 1.31 \\
\hline $\mathrm{S}-35$ & 323.83 & 4.87 & 2.52 \\
\hline $\mathrm{Sb}-124$ & 126.6 & 1.90 & 0.98 \\
\hline $\mathrm{Sb}-125$ & 126.33 & 1.90 & 0.98 \\
\hline $\mathrm{Se}-75$ & 218.33 & 3.28 & 1.70 \\
\hline $\mathrm{Se}-79$ & 212.87 & 3.20 & 1.70 \\
\hline $\mathrm{Sn}-113$ & 120.45 & 1.81 & 0.94 \\
\hline $\mathrm{Sn}-119 \mathrm{~m}$ & 119.04 & 1.79 & 0.94 \\
\hline $\mathrm{Sn}-121$ & 118.59 & 1.78 & 0.94 \\
\hline $\mathrm{Sn}-121 \mathrm{~m}$ & 118.59 & 1.78 & 0.94 \\
\hline $\mathrm{Sn}-123$ & 118.13 & 1.78 & 0.94 \\
\hline $\mathrm{Sn}-126$ & 117.47 & 1.77 & 0.94 \\
\hline
\end{tabular}

Notes: ${ }^{1}$ after Operations period 
Table 2-9. Effective Air Diffusion Coefficients $\left(D_{e}\right)$ for Each NRCDA Material

\begin{tabular}{|l|c|c|}
\hline Radionuclide & $\begin{array}{c}\mathbf{D}_{\mathbf{e}}\left(\mathbf{m}^{2} / \mathbf{y r}\right) \\
\text { NRCDA } \\
\text { Waste }\end{array}$ & $\begin{array}{c}\mathbf{D}_{\mathbf{e}}\left(\mathbf{m}^{2} / \mathbf{y r}\right) \\
\text { NRCDA } \\
\text { Clean Sand }\end{array}$ \\
\hline $\mathrm{C}-14$ & 152.52 & 6.22 \\
\hline $\mathrm{Cl}-36$ & 170.06 & 6.93 \\
\hline $\mathrm{I}-129$ & 90.73 & 3.70 \\
\hline $\mathrm{S}-35$ & 174.85 & 7.13 \\
\hline Sb-124 & 68.36 & 2.79 \\
\hline Sb-125 & 68.21 & 2.78 \\
\hline Se-75 & 117.88 & 4.80 \\
\hline Se-79 & 114.94 & 4.68 \\
\hline Sn-113 & 65.03 & 2.65 \\
\hline Sn-119m & 64.28 & 2.62 \\
\hline Sn-121 & 64.03 & 2.61 \\
\hline Sn-121m & 64.03 & 2.61 \\
\hline Sn-123 & 63.79 & 2.60 \\
\hline Sn-126 & 63.43 & 2.59 \\
\hline
\end{tabular}

Note: One of the assumptions for the NRCDA's is that the welded stainless steel waste containers provide a barrier that prevents the release of any radionuclides for 750 years. 
SRNL-STI-2011-00327

Revision 0

\subsection{Analysis and Results}

The ARM simulation computed the rate of diffusive flux at the land surface above each facility over the IC and post-Closure time periods. One of the purposes of the simulation was to establish the dose to the MEI with respect to time that results from placing a single $\mathrm{Ci}$ source term in each E-Area disposal facility. This dose is computed within the ARM model by first computing the diffusive flux of each radionuclide at the land surface and then multiplying that flux rate by the appropriate DRF for each facility with respect to time. Two DRFs are used for each facility, depending upon the location of the POC for the MEI. Initially the MEI is located at the SRS boundary and the E-Area is considered to be a point source, thus the same DRF is used for each disposal facility. During the post-Closure period (after $100 \mathrm{yr}$ of IC) a disposal facility specific DRF is available for each facility. The appropriate DRF is automatically invoked within the ARM depending on the elapsed time of the simulation.

The total simulation time was for 1000 years. This includes a 25 -yr operations period, a 100 -yr IC period and an additional 875-year post-Closure period. Although simulation of the operations period was not necessary in the analysis, it was retained in this model because it was built into the original ARM which was then easily adapted simply by changing the time in which the source term was inserted into it. The total 1000-yr simulation length was sufficient to observe the peak land surface fluxes for each E-Area disposal facility, although the simulation did not extend to the full 1000 years beyond the Final Closure (e.g., $\mathrm{t}=1125)$. The atmospheric releases from all facilities except the NRCDA's peak relatively early in this time period. The waste material loaded into the NRCDA's is contained within stainless steel vessels that are welded shut. The welds and walls of the vessel are assumed to retain their integrity for 750 years and only begin to release any remaining volatile inventory at that time.

Graphs of the radionuclide flux at the land surface above each E-Area disposal facility and graphs of the associated dose to the MEI are presented in the APPENDIX. There is one set of graphs for each disposal facility. An important feature to point out is that the graphs only indicate a surface flux and associated dose for C-14 and H-3. While the ARM evaluated the full suite of potentially volatile radionuclides identified in Table 2-1, it computes a zero flux for all other radionuclides at the land surface. The main factors in this phenomenon are the tendency of those radionuclides to partition into the available pore water of the disposal facility layers and overlying layers during the simulation and radioactive decay. Since no surface for all the potentially volatile radionuclides, except $\mathrm{C}-14$ and $\mathrm{H}-3$, occurs, they contribute no exposure to the MEI. As a result there is no disposal limit in any of the E-Area facilities for any of those radionuclides.

Table 3-1 presents the peak contaminant fluxes for C-14 and H-3 above each E-Area disposal facility and the elapsed time at which the peak occurred. Note that time $=25 \mathrm{yr}$ is the end of operations, time $=125 \mathrm{yr}$ is the end of IC, and times $>125 \mathrm{yr}$ represent the post-Closure period. Similarly, Table 3-2 presents the computed peak doses to the MEI that are associated with each E-Area disposal facility and the time of occurrence of that dose. 
Table 3-1. Peak Contaminant Fluxes and the Time of Peak

\begin{tabular}{|l|c|c|c|c|}
\hline & $\begin{array}{c}\text { Peak Flux H-3 } \\
(\mathbf{C i} / \mathbf{y r})\end{array}$ & $\begin{array}{c}\text { Time of Peak } \\
(\mathbf{Y r})\end{array}$ & $\begin{array}{c}\text { Peak Flux C-14 } \\
(\mathbf{C i} / \mathbf{y r})\end{array}$ & $\begin{array}{c}\text { Time of Peak } \\
(\mathbf{Y r})\end{array}$ \\
\hline ST/ET & $1.6 \mathrm{E}-12$ & 25 & $4.9 \mathrm{E}-01$ & 25 \\
\hline CIG & $1.4 \mathrm{E}-14$ & 125 & $1.4 \mathrm{E}-07$ & 25 \\
\hline LAWV & $1.2 \mathrm{E}-07$ & 102 & $1.4 \mathrm{E}-07$ & 26 \\
\hline ILV & $7.1 \mathrm{E}-13$ & 125 & $7.9 \mathrm{E}-08$ & 25 \\
\hline NRCDA 643-26E & NA & NA & $2.0 \mathrm{E}-02$ & 842 \\
\hline NRCDA 643-7E & NA & NA & $2.0 \mathrm{E}-02$ & 837 \\
\hline
\end{tabular}

Table 3-2. Peak Doses to the MEI and the Time of Peak

\begin{tabular}{|l|c|c|c|c|}
\hline & $\begin{array}{c}\text { Peak Dose H-3 } \\
(\mathbf{m r e m} / \mathbf{y r})\end{array}$ & $\begin{array}{c}\text { Time of Peak } \\
(\mathbf{Y r})\end{array}$ & $\begin{array}{c}\text { Peak Dose C-14 } \\
(\mathbf{m r e m} / \mathbf{y r})\end{array}$ & $\begin{array}{c}\text { Time of Peak } \\
(\mathbf{Y r})\end{array}$ \\
\hline ST/ET & $3.6 \mathrm{E}-18$ & 125 & $5.4 \mathrm{E}-05$ & 25 \\
\hline CIG & $3.1 \mathrm{E}-20$ & 125 & $2.9 \mathrm{E}-09$ & 145 \\
\hline LAWV & $2.6 \mathrm{E}-13$ & 102 & $2.8 \mathrm{E}-09$ & 138 \\
\hline ILV & $1.6 \mathrm{E}-18$ & 125 & $1.4 \mathrm{E}-08$ & 138 \\
\hline NRCDA 643-26E & NA & NA & $9.9 \mathrm{E}-04$ & 842 \\
\hline NRCDA 643-7E & NA & NA & $2.0 \mathrm{E}-03$ & 837 \\
\hline
\end{tabular}


SRNL-STI-2011-00327

Revision 0

\subsection{Plume Overlap Analysis}

As was described earlier, the primary motivation in updating the E-Area Low Level Waste facility atmospheric pathway models was to be able to address the concern of the LFRG PA review team regarding the need to assess the potential for overlapping atmospheric plumes during the IC period. During this period the POC (and therefore the location of potential impact) is located at the SRS boundary, at which distance the plumes emanating from separate facilities within E-Area may indeed co-mingle. Should atmospheric plumes co-mingle a dose to the MEI that is higher than expected dose from an individual facility could occur. This is the essence of the LFRG review team concern.

To evaluate this, a conservative approach is adopted in this SA whereby the MEI at the SRS boundary is exposed to the releases from all E-Area disposal facilities simultaneously. This is equivalent to evaluating a $100 \%$ overlap of all atmospheric plumes emanating from E-Area. Should the dose received from this level of atmospheric plume overlap still fall below the permissible exposure level of $10 \mathrm{mrem} / \mathrm{yr}$, then the LFRG issue would be demonstrated to no longer be a concern. The structuring of the ARM enables this evaluation to be easily performed.

The strategy in this analysis was to load the full radionuclide inventory that is anticipated for each E-Area disposal facility, as estimated in the 2008 PA (Appendix C, Closure Inventory Estimate), into their waste zones. Since it was demonstrated earlier that of all the potentially volatile radionuclides evaluated in this SA only C-14 and H-3 ever emanate from the land surface, those were the only radionuclides considered in the plume overlap analysis. Also, since both C-14 and H-3 have certain special waste forms listed in this inventory (e.g., resin based C-14) they were combined with the estimated total inventory of the generic isotope. This strategy is thought to be conservative since any special waste form would have a slower vapor release rate of the isotope than the generic form, which is assumed to be immediately available for vapor diffusion. This, in effect, causes the peak release rates to be higher than they otherwise would be if the special waste form inventory released more slowly. Table 4-1 summarizes the total anticipated inventory of C14 and H-3 for each E-Area disposal facility type.

Within the ARM the total dose delivered to the MEI was computed. The total dose comprises contributions from both C-14 and H-3 and from the contribution from all E-Area disposal facilities, simultaneously. Since individual facilities receive their total inventory emplacement simultaneously, there is a degree of temporal overlap as well as spatial overlap imbedded within the analysis. Combined, these conditions are thought to create a "worst-case" scenario for the MEI.

The results of this analysis, including the total plume overlap dose and the dose contribution from each individual E-Area disposal facility, are displayed in Figure 4-1. Total plume overlap dose is the sum of the individual facility doses contributed to the MEI and hence is essentially the trace of the uppermost individual facility dose contributions. Total dose is hidden behind the ILV total dose line, which dominates during IC and up until time $=750$ years, at which time NRCDA release of $\mathrm{C}-14$ begins to occur.

During the IC period, the peak of the "total plume overlap dose" was computed to 1.9E-05 $\mathrm{mrem} / \mathrm{yr}$, which occurs at time $=25$ years. Later, after the NRCDA begin to release C-14, the overall peak of the "total plume overlap dose" occurs. 
SRNL-STI-2011-00327

Revision 0

Table 4-1. ELLWF Estimated Inventory

\begin{tabular}{|c|c|c|c|c|}
\hline $\begin{array}{c}\text { Disposal } \\
\text { Facility } \\
\end{array}$ & & $\begin{array}{l}\text { C-14 } \\
\text { (Ci) } \\
\end{array}$ & & $\begin{array}{l}\text { H-3 } \\
\text { (Ci) } \\
\end{array}$ \\
\hline \multirow[t]{2}{*}{ East Slit } & C-14 & $3.0 \mathrm{E}-02$ & $\mathrm{H}-3$ & $1.2 \mathrm{E}+00$ \\
\hline & C14_NR.Pump ${ }^{2}$ & $8.2 \mathrm{E}-02$ & H-3_ETF.Carbon ${ }^{4}$ & $0.0 \mathrm{E}+00$ \\
\hline \multirow[t]{3}{*}{ Center Slit } & $\mathrm{C}-14$ & $1.0 \mathrm{E}-02$ & $\mathrm{H}-3$ & $1.0 \mathrm{E}+00$ \\
\hline & C-14_NR.Pump ${ }^{2}$ & $8.2 \mathrm{E}-02$ & H-3_ETF.Carbon ${ }^{4}$ & $2.8 \mathrm{E}-01$ \\
\hline & & & H-3 Concrete Co $^{5}$ & $3.9 \mathrm{E}+00$ \\
\hline \multirow[t]{2}{*}{ West Slit } & $\mathrm{C}-14$ & $1.8 \mathrm{E}-02$ & $\mathrm{H}-3$ & $5.5 \mathrm{E}-01$ \\
\hline & C-14_NR.Pump ${ }^{2}$ & $1.0 \mathrm{E}-03$ & & \\
\hline \multirow[t]{2}{*}{ ET } & $\mathrm{C}-14$ & $1.3 \mathrm{E}-01$ & $\mathrm{H}-3$ & $1.5 \mathrm{E}+00$ \\
\hline & Sum for ST/ET's & $3.5 \mathrm{E}-01$ & & $8.4 \mathrm{E}+00$ \\
\hline \multirow[t]{3}{*}{$\mathrm{CIG}$} & $\mathrm{C}-14$ & $1.1 \mathrm{E}-01$ & $\mathrm{H}-3$ & $1.1 \mathrm{E}+04$ \\
\hline & $\mathrm{C}-14 \mathrm{~K}^{3}$ & $2.3 \mathrm{E}-01$ & & \\
\hline & Sum for CIG & $3.4 \mathrm{E}-01$ & & $1.1 \mathrm{E}+04$ \\
\hline \multirow[t]{2}{*}{ LAWV } & $\mathrm{C}-14$ & $1.5 \mathrm{E}+00$ & $\mathrm{H}-3$ & $2.1 \mathrm{E}+07$ \\
\hline & Sum for LAWV & $1.5 \mathrm{E}+00$ & & $2.1 \mathrm{E}+07$ \\
\hline \multirow[t]{3}{*}{ ILV } & $\mathrm{C}-14$ & $3.9 \mathrm{E}+00$ & $\mathrm{H}-3$ & $1.5 \mathrm{E}+06$ \\
\hline & $\mathrm{C}-14 \mathrm{~KB}^{3}$ & $1.0 \mathrm{E}+03$ & H-3 TPB ${ }^{5}$ & $2.7 \mathrm{E}+06$ \\
\hline & Sum for ILV & $1.0 \mathrm{E}+03$ & & $4.2 \mathrm{E}+06$ \\
\hline $\begin{array}{l}\text { NRCDA } \\
663-26 \mathrm{E} \\
\end{array}$ & $\mathrm{C}-14$ & $3.4 \mathrm{E}+02$ & & \\
\hline $\begin{array}{l}\text { NRCDA } \\
663-7 E \\
\end{array}$ & $\mathrm{C}-14$ & $1.4 \mathrm{E}+02$ & & \\
\hline & Sum for NRCDA & $4.8 \mathrm{E}+02$ & & \\
\hline
\end{tabular}

${ }^{1}$ From Appendix C WSRC 2008. ${ }^{2}$ Special waste form C-14 Naval Reactor Main Coolant Pumps. ${ }^{3}$ Special waste form C-14_K and C-14_KB C-14 from K- and L-Area Basin Resins. ${ }^{4}$ Special waste form ETF Activated Carbon. ${ }^{5}$ Special waste form 232-F Concrete. ${ }^{6}$ TEF TPBAR tritium. Note: All Special waste forms are conservatively assumed to release at the same rate as the generic form.

The shape of the total plume overlap dose is shown in Figure 4-1. The total plume overlap dose during the IC period (0-125 years) is driven by H-3 releases. After the IC, total plume overlap dose illustrated in the figure is driven by $\mathrm{C}-14$ releases. The large jump that occurs at 750 years is from the C-14 release from NRCDA, as the steel vessels containing the C-14 waste are assumed to corrode all the way through, simultaneously.

The LFRG PA review team concern was for plume overlap occurring in the IC period and the worst case plume overlap dose is shown to be $1.9 \mathrm{E}-05 \mathrm{mrem} / \mathrm{yr}$ during this time-period, which is five orders of magnitude less than the PA performance measure of $10 \mathrm{mrem} / \mathrm{yr}$. It can safely be said that overlap of atmospheric plumes emanating from E-Area disposal facilities is not a concern during the IC period. 
Additionally, the potential for plume overlap was assessed in the post-Closure period. Atmospheric plume overlap is less likely to occur during this period but conceivably could occur if the prevailing wind direction shifted so as to pass directly over all E-Area disposal facilities and transport airborne radionuclides to the MEI at the $100 \mathrm{~m}$ POC. This was also demonstrated of little concern, as the maximum plume overlap dose was found to be $1.45 \mathrm{E}+00 \mathrm{mrem} / \mathrm{yr}$ (or $\sim 15 \%$ of the performance measure) during this period and under these unlikely conditions.

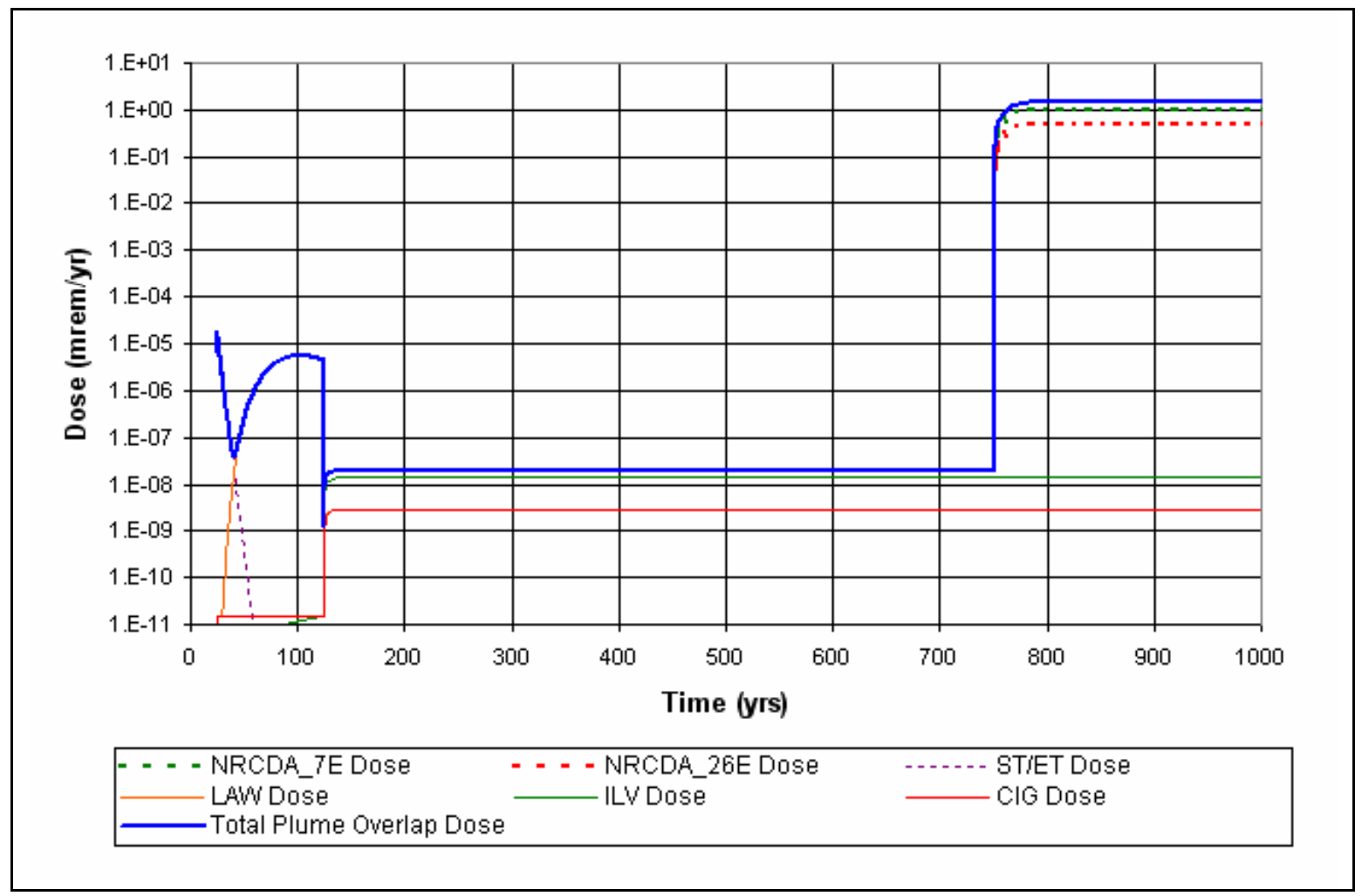

Figure 4-1. Plume Overlap Dose and Dose from Individual Disposal Facilities 


\subsection{Conclusions}

This SA was initiated to address a concern expressed by DOE's LFRG Review that the potential for overlapping of atmospheric plumes, emanating from the soil surface above SRS LLW disposal facilities within the E-Area, would contribute to the dose received by a member of the public during the IC period. In the process of developing a new ARM capable of addressing this concern, it became obvious that new and better atmospheric pathway disposal limits should be developed for each of the E-Area LLWF disposal facilities.

In this analysis using the improved ARM it was discovered that, even though the full suite of potentially volatile radionuclides identified in Table 2-1 were introduced into the model, it computes a zero flux at the land surface for all of the radionuclides except $\mathrm{C}-14$ and $\mathrm{H}-3$. The main factors in this phenomenon are the tendency of those radionuclides to partition into the available pore water of the disposal facility and overlying layers during the simulation and radioactive decay. Thus, these two radionuclides are the only ones for which new atmospheric pathway disposal limits are presented for the E-Area disposal facilities. These new disposal limits are presented in Table 5-1, along with a listing of the former disposal limits determined in the 2008 PA.

Table 5-1. Updated Atmospheric Pathway Disposal Limits

\begin{tabular}{|c|c|c|c|c|}
\hline & $\begin{array}{c}\text { PA Atm. } \\
\text { Pathway } \\
\text { Disposal Limit } \\
\text { (Ci/facility) }\end{array}$ & $\begin{array}{c}\text { New Atm. } \\
\text { Pathway } \\
\text { Disposal Limit } \\
\text { (Ci/facility) }\end{array}$ & $\begin{array}{l}\text { PA Anticipated } \\
\text { Inventory } \\
\text { (Ci) }\end{array}$ & $\begin{array}{c}\text { Pathway that } \\
\text { Limits } \\
\text { Disposal }^{2}\end{array}$ \\
\hline C-14 in Slit $E^{1}$ & $2.9 \mathrm{E}+05$ & $1.9 \mathrm{E}+05$ & $1.1 \mathrm{E}-01$ & B-G; $12-100 \mathrm{yr}$ \\
\hline C-14 in Slit $W^{1}$ & $2.9 \mathrm{E}+05$ & $1.9 \mathrm{E}+05$ & $1.9 \mathrm{E}-02$ & B-G; 0-12 yr \\
\hline C-14 in Slit $C^{1}$ & $2.9 \mathrm{E}+05$ & $1.9 \mathrm{E}+05$ & $9.2 \mathrm{E}-02$ & B-G; $12-100 \mathrm{yr}$ \\
\hline C-14 in ET & $2.9 \mathrm{E}+05$ & $1.9 \mathrm{E}+05$ & $1.3 \mathrm{E}-01$ & B-G; $12-100 \mathrm{yr}$ \\
\hline H-3 in Slit $E^{1}$ & $1.1 \mathrm{E}+07$ & $2.8 \mathrm{E}+18$ & $1.2 \mathrm{E}+00$ & B-G; $12-100 \mathrm{yr}$ \\
\hline H-3 in Slit $W^{1}$ & $1.1 \mathrm{E}+07$ & $2.8 \mathrm{E}+18$ & $5.5 \mathrm{E}-01$ & B-G; 0-12 yr \\
\hline H-3 in Slit $C^{1}$ & $1.1 \mathrm{E}+07$ & $2.8 \mathrm{E}+18$ & $5.2 \mathrm{E}+00$ & B-G; $12-100 \mathrm{yr}$ \\
\hline H-3 in ET & $1.1 \mathrm{E}+07$ & $2.8 \mathrm{E}+18$ & $1.5 \mathrm{E}+00$ & B-G; $12-100 \mathrm{yr}$ \\
\hline C-14 in CIG & $1.7 \mathrm{E}+06$ & $3.4 \mathrm{E}+09$ & $3.4 \mathrm{E}-01$ & B-G $125-1125 \mathrm{yr}$ \\
\hline $\mathrm{H}-3$ in CIG & $3.1 \mathrm{E}+07$ & -- & $1.1 \mathrm{E}+04$ & B-G $125-1125 \mathrm{yr}$ \\
\hline C-14 in ILV & $2.2 \mathrm{E}+05$ & $7.4 \mathrm{E}+08$ & $1.0 \mathrm{E}+03$ & B-G 200-1100 \\
\hline $\mathrm{H}-3$ in ILV & $3.8 \mathrm{E}+06$ & $6.4 \mathrm{E}+18$ & $4.2 \mathrm{E}+06$ & B-G 200-1100 \\
\hline C-14 in LAWV & $3.3 \mathrm{E}+03$ & $3.5 \mathrm{E}+09$ & $1.5 \mathrm{E}+00$ & B-G \\
\hline H-3 in LAWV & $1.1 \mathrm{E}+08$ & $3.8 \mathrm{E}+13$ & $2.1 \mathrm{E}+07$ & B-G \\
\hline C-14 in NR 643-26E & $2.6 \mathrm{E}+03$ & $1.0 \mathrm{E}+04$ & $3.4 \mathrm{E}+02$ & Atmospheric \\
\hline C-14 in NR 643-7E & $5.3 E+02$ & $4.9 \mathrm{E}+03$ & $1.4 \mathrm{E}+02$ & Atmospheric \\
\hline
\end{tabular}

Note: ${ }^{1}$ The new limits apply to each trench within the East, Center and West grouping of trenches

${ }^{2}$ This is the pathway predicted in the 2008 PA to limit disposal. 
Outside of C-14 and H-3, all of the other potentially volatile radionuclides, except Sn-121, had a disposal limit computed within the 2008 PA. Those limits no longer apply, and Sn-121 retains it status as having no Air-pathway limit.

Also listed is the expected total inventory for each of the radionuclides for each disposal facility and the identity of the release pathway that limits disposal for that facility. Special waste forms are considered to have the same disposal limit as the updated generic radionuclide disposal limits with the exception of the H3 TPBAR special waste form and the IP-2 boxes for disposing H-3, which are not evaluated in this SA. Therefore, the H3_TPBAR and H-3_IP2 Air pathway disposal limits for the ILV, both previously established, still apply. The H3_TPBAR Air pathway disposal limit was 9.4E+10 Ci (Hiergesell, 2005) and the H3 IP2 Air pathway disposal limit was calculated to be $4.6 \mathrm{E}+08 \mathrm{Ci}$ (Swingle, 2008b). Both limits are lower than the generic H-3 Air pathway limit calculated in this SA and listed in Table 5-1. In addition the 4 SA's and 10 UDQEs conducted since the 2008 PA was issued were examined to determine if they altered the Atmospheric pathway disposal limits. None were found.

The most obvious change in limits is a significant increase in the H-3 disposal limits for all EArea disposal facilities and a significant increase in the $\mathrm{C}-14$ disposal limit for those facilities containing concrete-like material (e.g. Vaults and CIG).

For H-3, this is attributed to the inclusion of the mechanism to partition vapor-borne H-3 across the air-water interface using Henry's Law constants. The magnitude of change for these disposal facilities is an increase of 11 to 13 orders of magnitude. Although these disposal limits are quite high, the atmospheric release pathway is not the limiting pathway for any of the disposal facilities. In actuality, most of the H-3 partitions into water and is released through the groundwater pathway, thus that pathway is limiting, in terms of establishing H-3 disposal limits for E-Area disposal facilities.

The most obvious changes in limits is a significant increase in the $\mathrm{H}-3$ disposal limits for all EArea disposal facilities and a significant increase in the $\mathrm{C}-14$ disposal limit for those facilities containing concrete-like material (e.g. Vaults and CIG). For H-3, this is attributed to the inclusion of the mechanism to partition vapor-borne $\mathrm{H}-3$ across the air-water interface using Henry's Law constants. The magnitude of change for these disposal facilities is an increase of 11 to 13 orders of magnitude. Although these disposal limits are quite high, the atmospheric release pathway is not the limiting pathway for any of the disposal facilities. In actuality, most of the H-3 partitions into water and is released through the groundwater pathway, thus that pathway is limiting, in terms of establishing H-3 disposal limits for E-Area disposal facilities. In regard to the C-14 disposal limits, a sharp increase of 4-5 orders of magnitude are noted for the CIG, ILV and LAWV. The reason for this is the imposition of the maximum $\mathrm{C}-14_{(\mathrm{g})}$ concentration in the airfilled pores of cementitious materials. Each of the facilities with increased C-14 disposal limits contains a cementitious material either within its waste emplacement zone or in vault walls, floor and roof. The Slit and Engineered trenches do not have cementitious material and therefore the new disposal limits are very similar to those determined in the 2008 PA.

The main conclusion of this study is that for atmospheric releases from the E-Area disposal facilities, plume overlap does not cause the total dose to the MEI at the SRS boundary during IC to exceed the PA performance objective. This conclusion directly addresses the LFRG PA review team issue. Furthermore, even though the LFRG comment did not express concern for such overlap to occur during the post-Closure period, applying the $100 \%$ plume overlap strategy to atmospheric releases during this period also demonstrates that the PA performance objective for the MEI will also not be exceeded during that time-frame either. 
SRNL-STI-2011-00327

Revision 0

\subsection{Key Inputs and Assumptions}

This section identifies the key inputs and assumptions that are applicable for this SA. It should be noted that all of the key inputs and assumptions identified for the Atmospheric Pathway in Appendix B of the 2008 PA still apply, except for those which apply to the Operations Period. Related to this, the annual and 25-year disposal limit for H-3 in the LAW Vault (see Table 3-45 in Part B of WSRC-STI-2007-00306, Revision 1) no longer apply. The key I\&A's that are no longer applicable are clearly indicated below and one key I\&A for the Air pathway is added.

Since the 2008 PA was issued, there have been 4 SA's and 10 UDQE's conducted that relate to disposal facilities within E-Area. Each of these studies were reviewed to determine if they create any Input and Assumptions that relate to the Air release pathway. These reports are listed below.

Unreviewed Disposal Question Evaluations:

- High Curie Content Waste Container in the E-Area Low Level Waste Facility Intermediate Level Vault (R.S. Swingle, 2008a)

- Engineered Trench Sump Closure and Replacement (E.W. Wilhite, et. al, 2009)

- Installation of Additional Concrete Anchors in the Floor of the LAW Vault Cell 11 to Support an Extension of the Temporary Air Lock Enclosure. (W.E. Jones, et. al. 2010)

- Transcription Error in Appendix C of the 2008 E-Area Low Level Waste Facility Performance Assessment. (R.S. Swingle, 2009)

- Disposal of Tall Used Equipment Storage Boxes in Slit Trench Numbers 8, 9, and 10. (G.P. Flach, et.al. 2010)

- $\quad$ Slit Trench Waste with High Inventory Limit Consumption and Mischaracterized Waste (L.B. Collard, 2008)

- Issues Associated with Disposal of the Heavy Water Components Test Reactor (F.S. Smith, et.al., 2011b)

- Center Slit Trenches One through Five Operational Covers Re-Analysis (F.G. Smith et.al., 2011a)

- Disposal of Tall Used Equipment Storage Boxes Number 5 and Number 42 in Slit Trench Number 8. (W.E. Jones, et.al. 2009)

- $\quad$ E-Area Low Level Waste Facility Completion Project (J.M. Jordan et.al. 2009)

Special Analyses

- Special Analysis Disposal of Tritium-Containing IP-2 Boxes in the E-Area Low Level Waste Facility Intermediate Level Vault.(R.S. Swingle, 2008b)

- Special Analysis for Slit Trench Disposal of the Heavy Water Components Test Reactor. (L.L. Hamm, et.al. 2010)

- Special Analysis of Operational Stormwater Runoff Covers Over Slit Trenches. (L.B. Collard, et.al. 2008)

- Special Analysis of Tritium Disposal Limits for E-Area Slit Trench 4, (L.B. Collard et. al. 2010) 
SRNL-STI-2011-00327

Revision 0

These reports were reviewed to determine if any of the key inputs and assumptions impacted this SA. No conditions were identified that would produce results that are not bounded by the key inputs and assumptions that apply to the Air pathway analysis of this SA.

Atmospheric (Air) Pathway Key Input and Assumptions from the 2008 PA which no longer apply are listed below:

- Key I\&A 5.8.3. This item discusses a condition that exists in the Operations Period. It is no longer applicable because this SA establishes that the PA Air Pathway performance objective is not evaluated during the Operations Period.

- Key I\&A 5.8.4. This item discusses a condition that exists in the Operations Period. It is no longer applicable be cause this SA establishes that the PA Air Pathway performance objective is not evaluated during the Operations Period.

- Key I\&A 5.8.5 This item discusses a condition that exists in the Operations Period. It is no longer applicable because this SA establishes that the PA Air Pathway performance objective is not evaluated during the Operations Period.

A new Key Input and Assumption is introduced in this SA and is listed below.

- This SA assumes that the entire source term is loaded into the waste zones of all disposal facilities at the end of the Operations Period. While this assumption does not reflect the actual mode of waste emplacement in disposal facilities, it leads to a slight overestimation of the radionuclide flux at the land surface from that point forward and therefore introduces a measure of conservatism when evaluating the dose to the MEI during the PA compliance period. This assumption applies to all E-Area disposal facilities but places no constraint upon the operators in terms of when waste is emplaced within disposal facilities during the Operations Period.

A final point is worth mentioning with regard to Key Input and Assumption 5.8.15. This I\&A requires that the SOF from all E-Area disposal facilities combined will not exceed a SOF of 1. This requirement is demonstrated by the main conclusion of this SA, which states that plume overlap in the Air pathway does not cause the MEI to receive a dose in excess of the PA performance objective in the IC period, therefore the I\&A control cited in the Ops Parameter found in Key I\&A 5.8.15 is no longer applicable and control will now be administered by this SA.. This, in essence, means that the SOF from all facilities combined does not reach or exceed 1. This SA also demonstrates that the same is true for the post-IC period, as well. 
SRNL-STI-2011-00327

Revision 0

\subsection{References}

Beres, D. A. 1990. The Clean Air Act Assessment Package-1988 (CAP-88) A Dose and Risk Assessment Methodology for Radionuclide Emissions to Air. U.S. Environmental Protection Agency Contract No. 68-D9-0170, Washington, DC.

Bolz, R. E. and G. L. Tuve, (Editors), 1973. Handbook of Tables for APPLIED ENGINEERING SCIENCE, 2nd Edition. CRC Press, 18901 Cranwood Parkway, Cleveland, OH.

Collard, L.B., L.L. Hamm and F.G. Smith. 2010. Special Analysis of Tritium Disposal Limits for E-Area Slit Trench 4. SRNL-STI-2010-00263, Rev. 0. Savannah River National Laboratory, Aiken, SC 29808.

Collard, L.B. 2008. Slit Trench Waste with High Inventory Limit Consumption and Mischaracterized Waste. SRNL-STI-2008-00520, Rev. 0. Savannah River National Laboratory, Aiken, SC 29808.

Collard, L.B. and L.L. Hamm. 2008. Special Analysis of Operational Stormwater Runoff Covers Over Slit Trenches. SRNL-STI-2008-00397, Rev. 0. Savannah River National Laboratory, Aiken, SC 29808.

Crapse, K. P. and J. R. Cook, 2006. Atmospheric Pathway Screening Analysis for the E-Area Low Level Waste Facility, WSRC-STI-2006-00159, Washington Savannah River Company, Aiken, SC 29808. 09/05/2006.

Dayal, R., H. Johnston, and Z. Zhou. 1989. Reactor Operating Waste Disposal Program - 1989 Progress Report. 89-226-K, Ontario Hydro Research Division, Ontario, Canada.

Dayal, R. and E.J Reardon. 1992. Cement-Based Engineered Barriers for Carbon-14 Isolation. Waste Management 12: 189-200.

Denham, M. E. 2010a. Conceptual Model of Waste Release from the Contaminated Zone of Closed Radioactive Waste Tanks. WSRC-STI-2007-00544 Rev. 2. Savannah River National Laboratory. Aiken, SC.

Denham, Miles. 2010b. Vapor - Aqueous Solution Partition Coefficients for Radionuclides Pertinent to High Level Waste Tank Closure. SRNL-TR-2010-00096. Savannah River National Laboratory. Aiken, SC.

EPA, 2002. U.S. Environmental Protection Agency, 2002, "National Emission Standards for Hazardous Air Pollutants," Title 40 Code of Federal Regulations, Part 61, Subpart H, September 2002, Washington, D.C.

DOE 1999. Implementation Guide for Use with DOE M 435.1-1. DOE G 435.1-1. U. S. Department of Energy, July 9, 1999. 
SRNL-STI-2011-00327

Revision 0

Flach, G.P. and W.E. Jones. 2010. Unreviewed Disposal Question Evaluation: Disposal of Tall Used Equipment Storage Boxes in Slit Trench Numbers 8, 9 and 10. SRNL-STI-2010-00799, Rev. 0. Savannah River National Laboratory, Aiken, SC 29808.

GTG. 2009. GoldSim ${ }^{\circledR}$ User's Guide Version 10.0. GoldSim ${ }^{\circledR}$ Technology Group. Issaquah, WA.

Hamm, L.L. and F.G. Smith. 2010. Special Analysis for Slit Trench Disposal of the Heavy Water Components Test Reactor. SRNL-STI-2010-00574, Rev. 0. Savannah River National Laboratory, Aiken, SC 29808.

Hiergesell, R. A. 2005. Special Analysis: Production TPBAR Waste Container Disposal Within the Intermediate Level Vault. WSRC-TR-2005-00531, Rev. 0. Savannah River National Laboratory, Aiken, SC 29808.

Hiergesell, R.A. and R.S. Swingle. 2005. Special Analysis: Atmospheric Dose Resulting from the Release of ${ }^{14}$ C from Reactor Moderator Deionizers in a Disposal Environment (U). WSRC-TR2005-00331, Rev. 0. Washington Savannah River Company, Aiken, SC 29808.

Jones, W.E. 2010. Unreviewed Disposal Question Evaluation: Installation of Additional Concrete Anchors in the Floor of the LAW Vault Cell 11 to Support an Extension of the Temporary Air Lock Enclosure. SRNL-TR-2010-00196, Rev. O. Savannah River National Laboratory, Aiken, SC 29808.

Jones, W.E., E.L. Wilhite and B.T. Butcher. 2009. Unreviewed Disposal Question Evaluation: Disposal of Tall Used Equipment Storage Boxes Number 5 and Number 42 in Slit Trench Number 8. SRNL-TR0-2009-00236, Rev. 0. Savannah River National Laboratory, Aiken, SC 29808.

Jordan, J.M. and G.P. Flach. 2009. Unreviewed Disposal Question Evaluation: E-Area Low Level Waste Facility Completion Project. SRNL-TR-2009-00207, Rev. 0. Savannah River National Laboratory, Aiken, SC 29808.

Kaplan, D.I. 2005. Estimate of Gaseous ${ }^{14} \mathrm{C}$ Concentrations Emanating from the IntermediateLevel Vault Disposal Facility (U). WSRC-TR-2005-00222, Rev. 0. Westinghouse Savannah River Company. Aiken, SC 29808.

Lee, P. 2006. Atmospheric Dose Modeling for the E-Area Low Level Waste Facility at the Savannah River Site, WSRC-STI-2006-00262, Washington Savannah River Company, Aiken, SC 29808.

Nielson, K. K., V.C. Rogers and G.W. Gee, 1984. Diffusion of Radon through Soils: A pore distribution Model, Soil Science Society of America, J. 48:482-487.

Phifer, M. A., Millings, M. R., and Flach, G. P. 2006. Hydraulic Property Data Package for the E-Area And Z-Area Vadose Zone Soils, Cementitious Materials, and Waste Zones. WSRC-STI-2006-00198. Washington Savannah River Company, Aiken, SC. September 2006.

Sandler, Rolf. 1997. Converting Henry's Law Constants. http://www.mpchmainz.mpg.de/ sander/res/henry-conv.html. Max Plank Institute for Chemistry, Mainz, Germany. 
SRNS 2010. Savannah River Site Environmental Report for 2009. SRNS-STI-2010-00175. Savannah River Nuclear Solutions, Aiken, SC 29808.

SRNL 2009. Closure Plan for the E-Area Low-Level Waste Facility. SRNL-RP-2009-00075, Rev. 0. Savannah River National Laboratory. Aiken, SC 29808.

Smith, F.G. and R.S. Swingle. 2011a. Unreviewed Disposal Question Evaluation: Center Slit Trenches One through Five Operational Covers Re-Analysis. SRNL-STI-2011-00257, Rev. 0. Savannah River National Laboratory. Aiken, SC 29808.

Smith, F.S. and R.S. Swingle. 2011b. Unreviewed Disposal Question Evaluation: Issues Associated with Disposal of the Heavy Water Components Test Reactor. SRNL-STI-2011-00203, Rev. 0. Savannah River National Laboratory. Aiken, SC 29808.

Swingle, R.F. 2009. Unreviewed Disposal Question Evaluation: Transcription Error in Appendix C of the 2008 E-Area Low Level Waste Facility Performance Assessment. SRNL-RP-200900273, Rev. 0. Savannah River National Laboratory. Aiken, SC 29808.

Swingle, R.F. 2008a. Unreviewed Disposal Question Evaluation: High Curie Content Waste Container in the E-Area Low Level Waste Facility Intermediate Level Vault. SRNL-TR-200800316, Rev. 0. Savannah River National Laboratory, Aiken, SC 29808.

Swingle, R.F. 2008b. Special Analysis Disposal of Tritium-Containing IP-2 Boxes in the E-Area Low Level Waste Facility Intermediate Level Vault. SRNL-STI-2008-00453, Rev. 0. Savannah River National Laboratory, Aiken, SC 29808.

Wilhite, E.L., B.T. Butcher, M.A. Phifer and S.R. Reed. 2009. Unreviewed Disposal Question Evaluation: Engineered Trench Sump Closure and Replacement. SRNL-TR-2009-00042, Rev.0. Savannah River National Laboratory, Aiken, SC 29808

WSRC. 2008. E-Area Low-Level Waste Facility DOE 435.1 Performance Assessment. WSRCSTI-2007-00306, Revision 0. Washington Savannah River Company. Aiken, SC. 
SRNL-STI-2011-00327

Revision 0

APPENDIX: Atmospheric Pathway Flux at Land Surface and Doses to MEI from Unit Source Term 


\section{$\underline{\text { Slit and Engineered Trenches }}$}

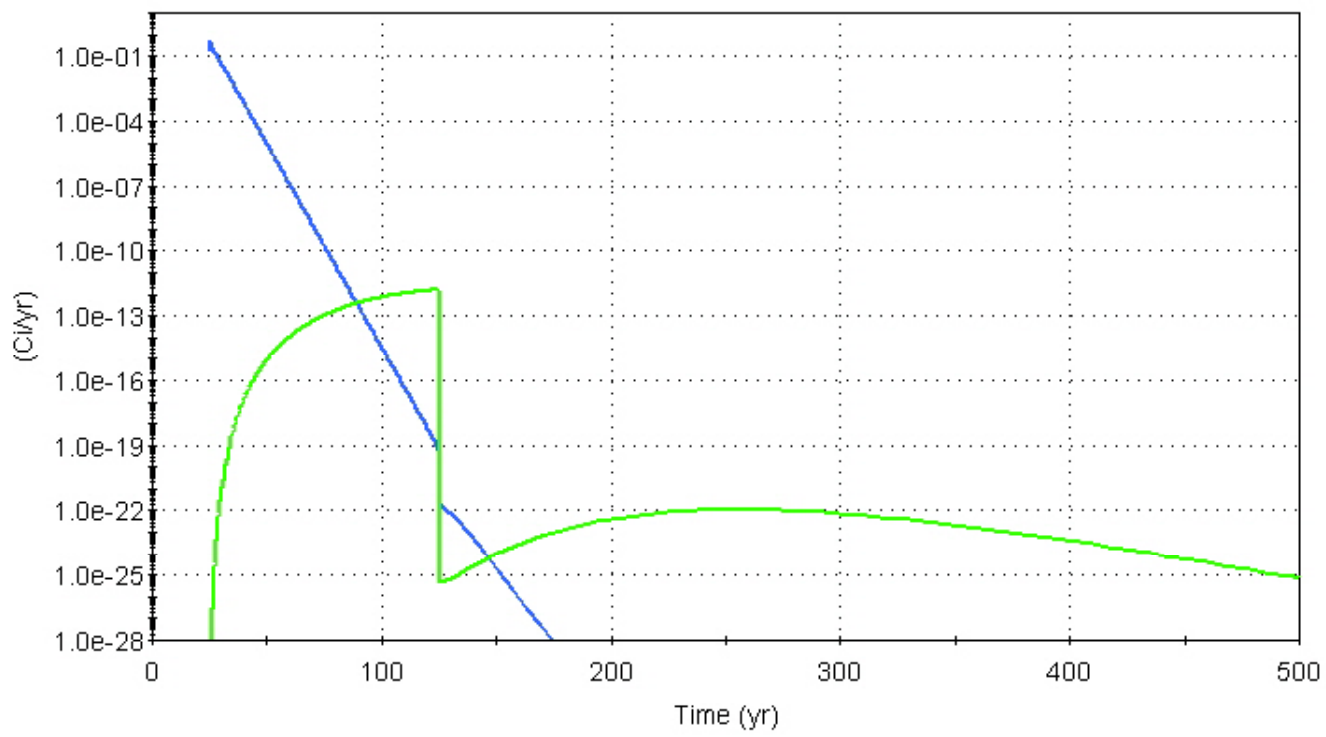

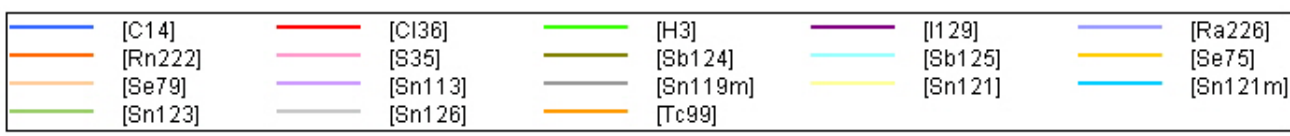

Flux at Land Surface

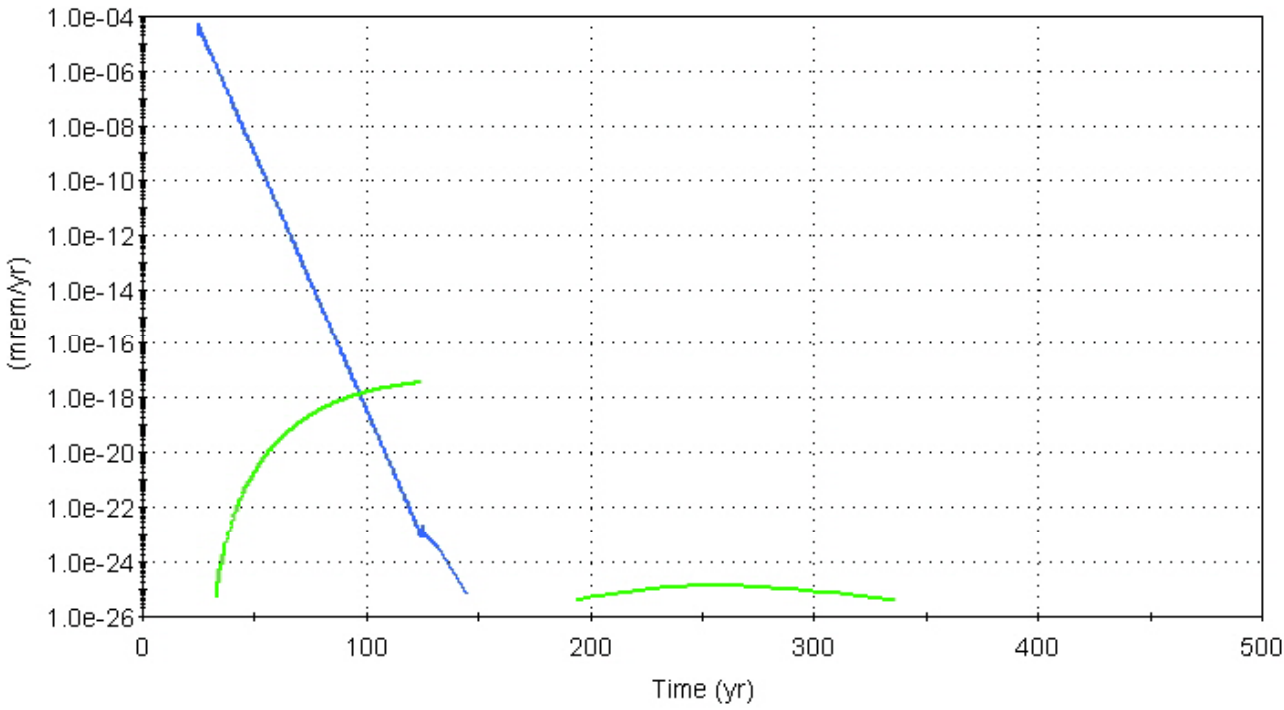

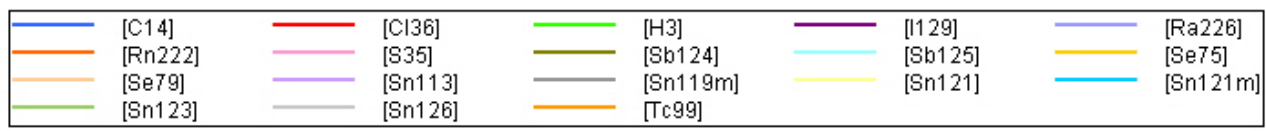

Dose to MEI 


\section{$\underline{\text { Components in Grout Trenches }}$}

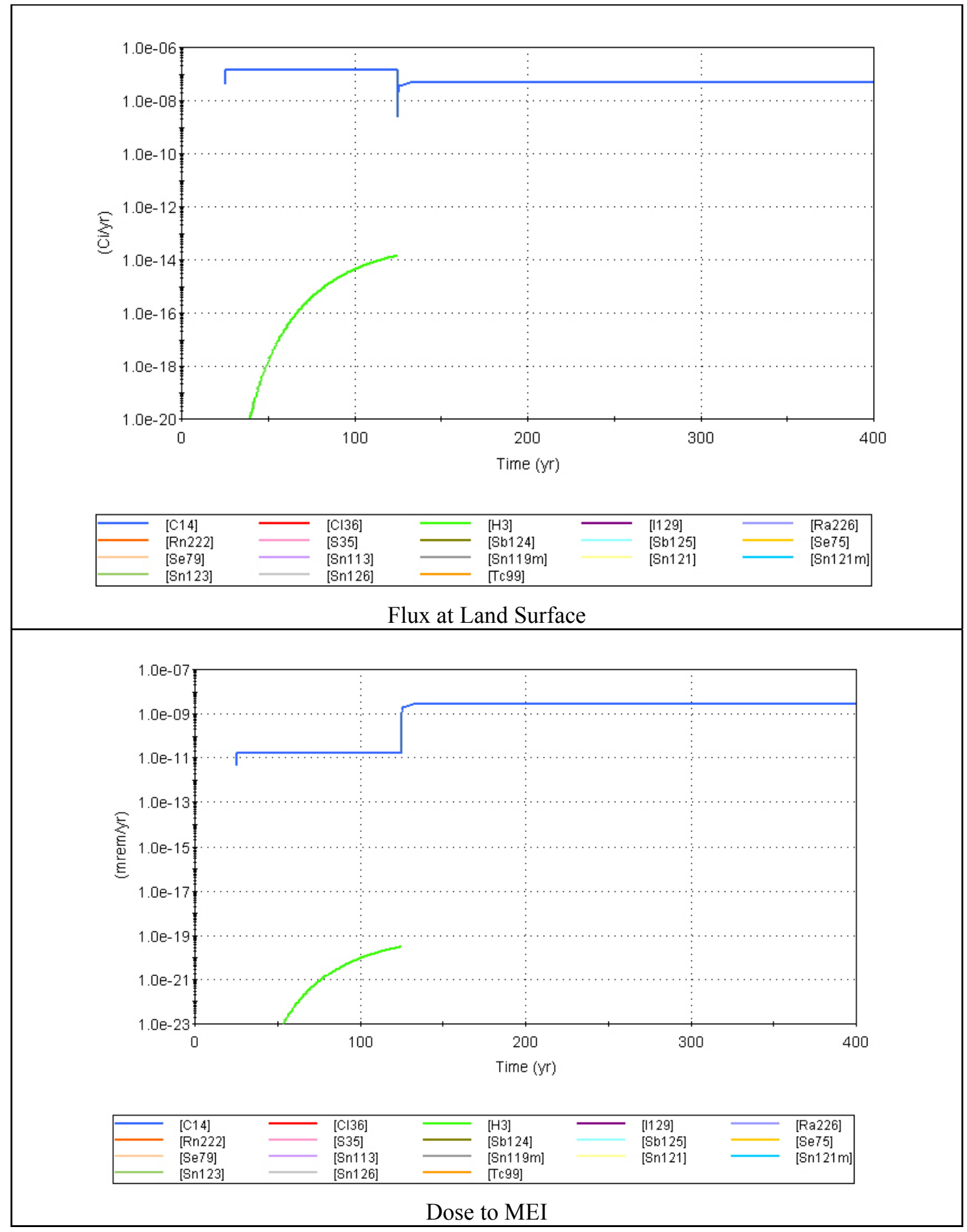


$\underline{\text { Low Activity Waste Vaults }}$

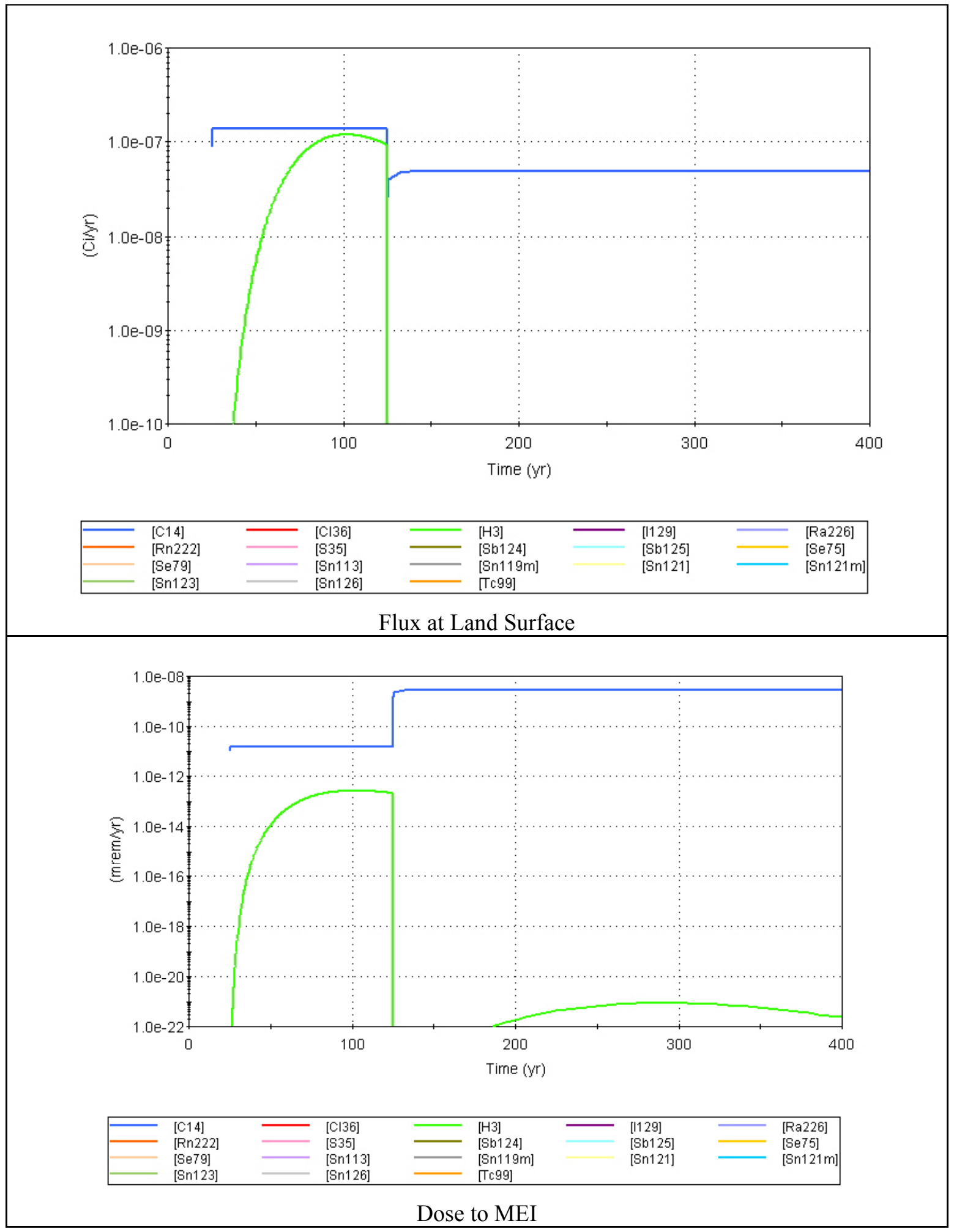


$\underline{\text { Intermediate Level Vaults }}$

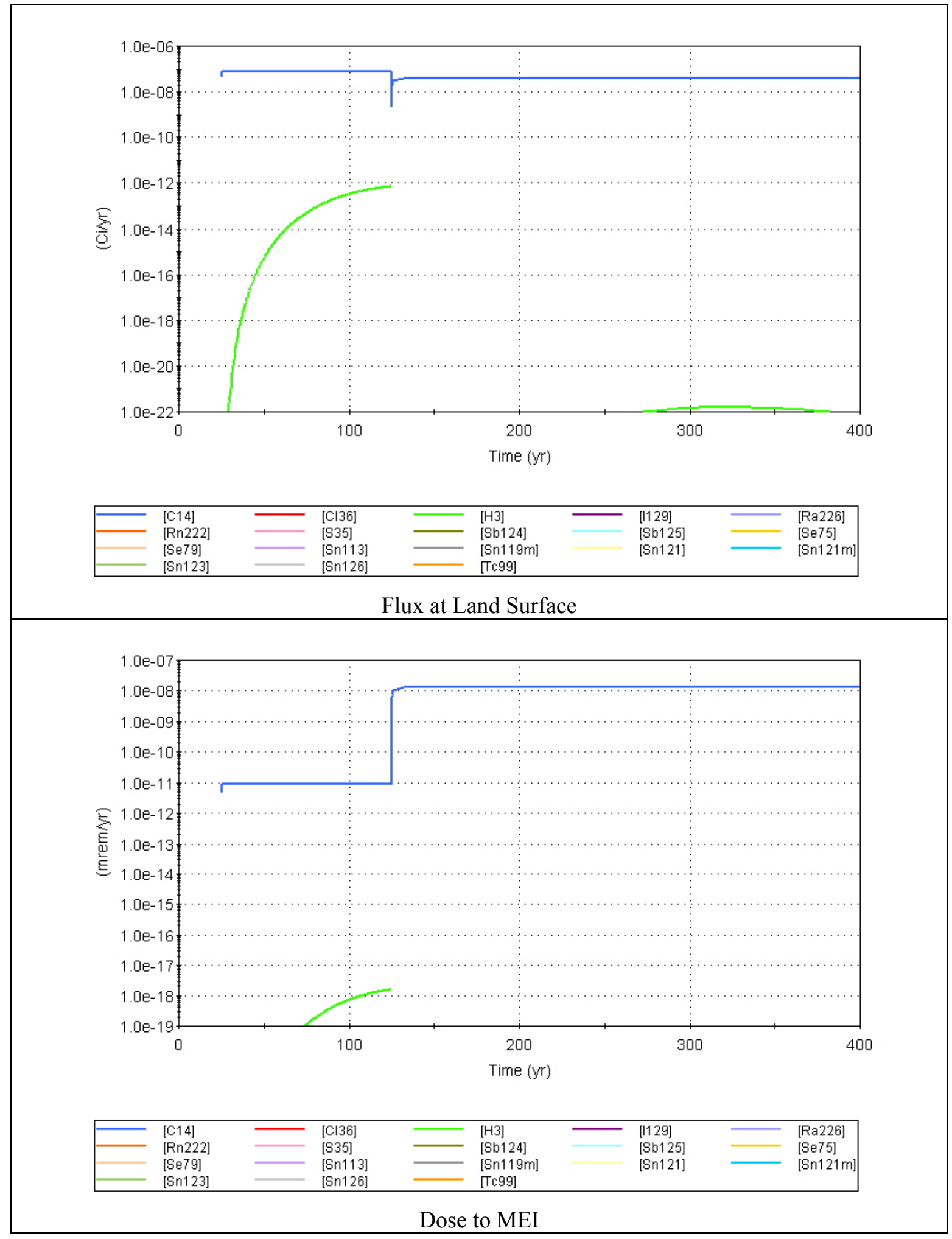


SRNL-STI-2011-00327

Revision 0

$\underline{\text { NRCDA Pad 7E }}$

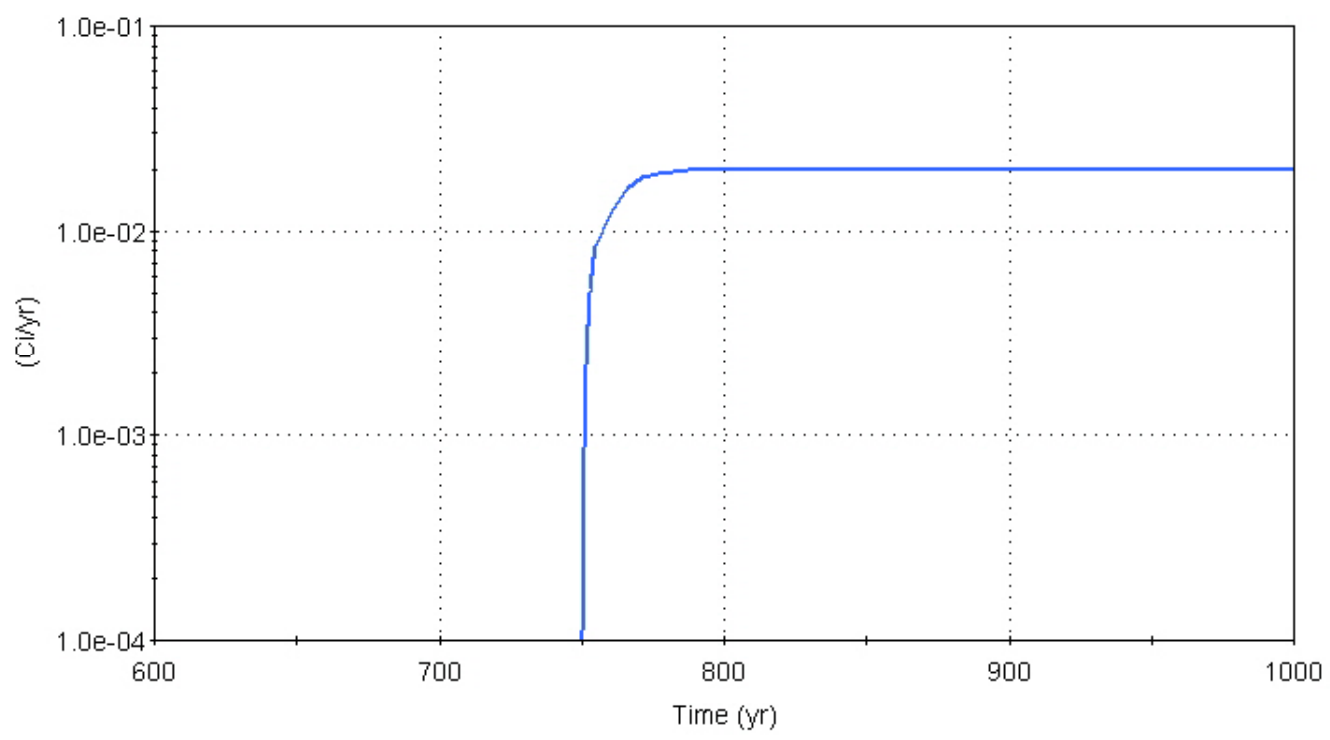

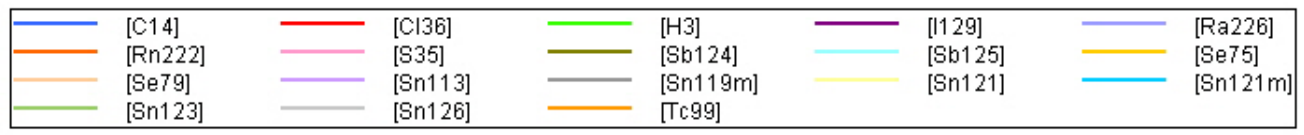

Flux at Land Surface

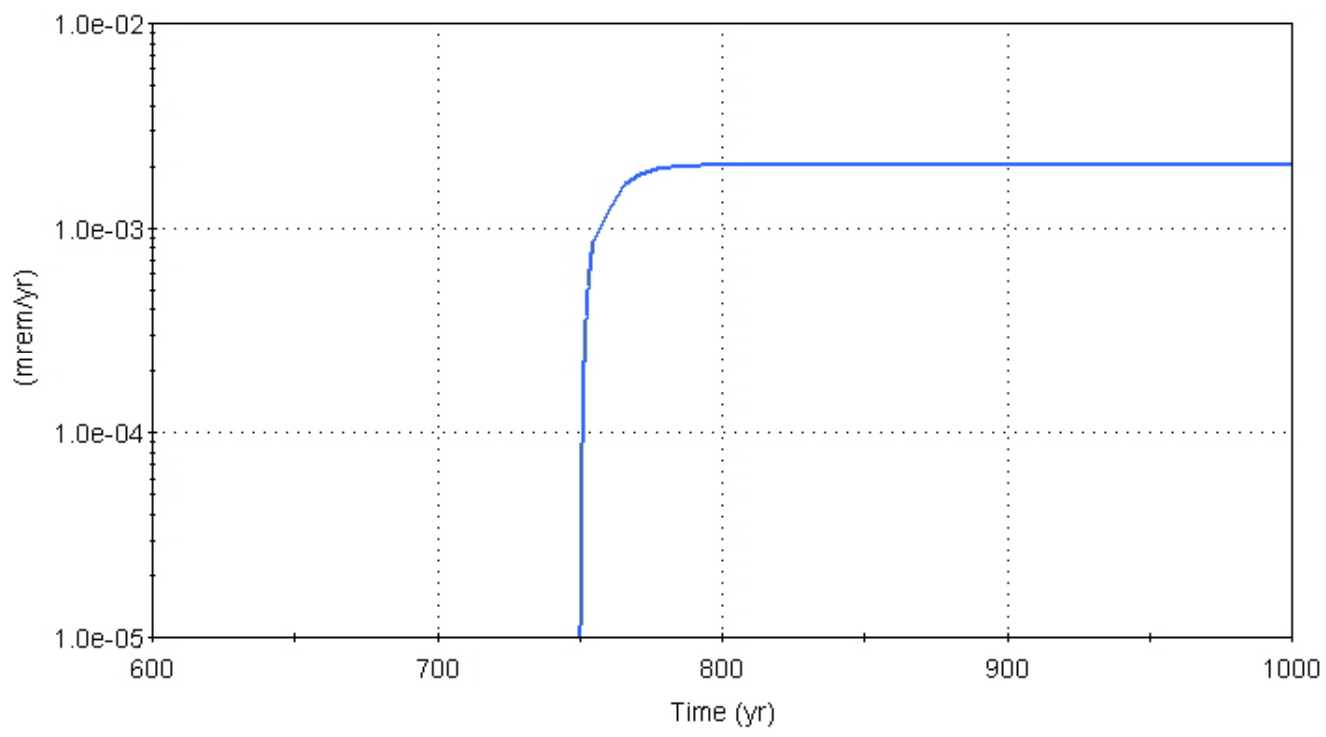

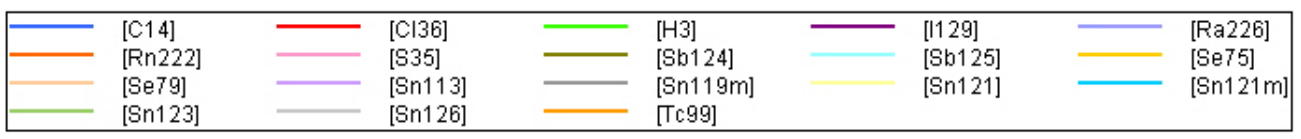

Dose to MEI 
SRNL-STI-2011-00327

Revision 0

$\underline{\text { NRCDA Pad 26E }}$

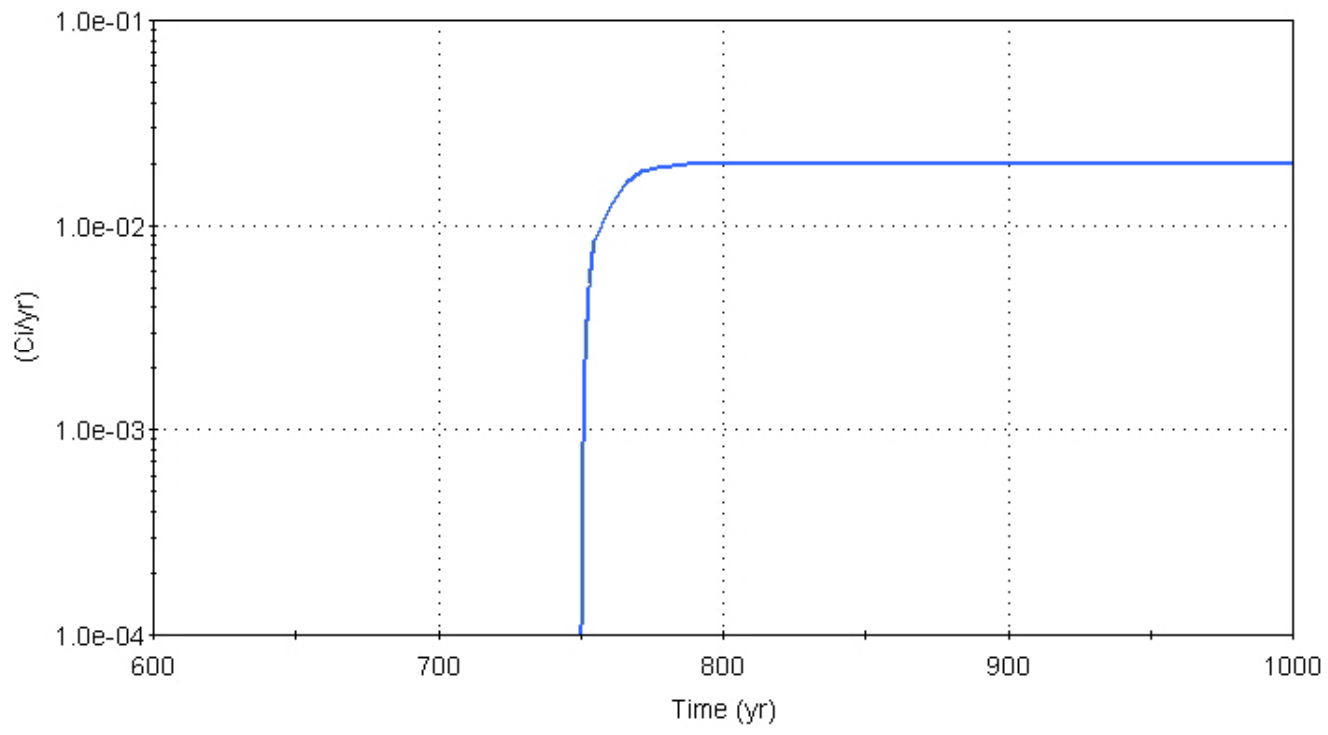

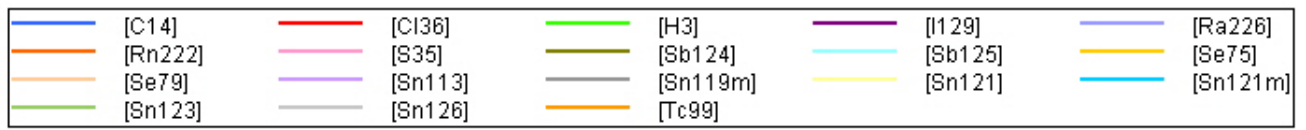

Flux at Land Surface

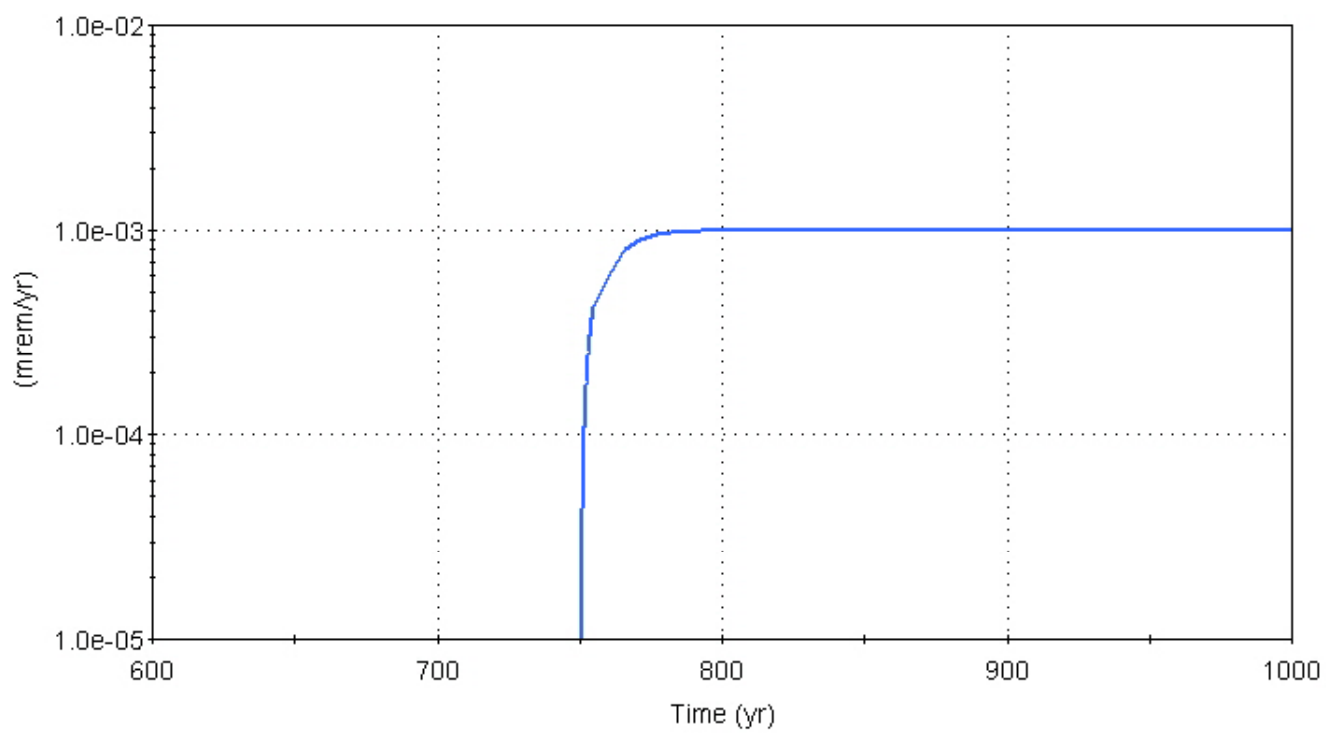

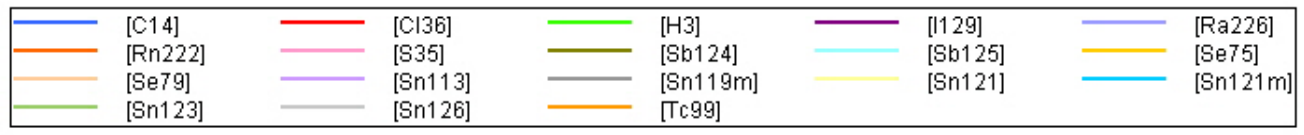

Dose to MEI 
SRNL-STI-2011-00327

Revision 0

This page is left blank intentionally 
SRNL-STI-2011-00327

Revision 0

\section{Distribution:}

R. S. Aylward, 773-42A

L. A. Bagwell, 773-42A

D. L. Beeler, 704-60E

H. H. Burns, 773-41A

B. T. Butcher, 773-43A

L. B. Collard, 773-43A

D. A. Crowley, 773-43A

G. P. Flach, 773-42A

F. L. Fox, 704-59E

J. C. Griffin, 773-A

L. L. Hamm,703-41A

M. A. Heitkamp, 999-W

S. J. Hensel, 703-41A

R. A. Hiergesell, 773-43A

G. K. Humphries, 705-3C

J. M. Jordan, 703-41A

K. M. Kostelnik, 705-3C

D. I. Kaplan, 773-43A

D. Li, $773-43 \mathrm{~A}$

M. G. Looper, 704-36E

J. J. Mayer, 773-42A

M. R. Millings, 773-42A

T. O. Oliver, 773-42A

M. A. Phifer, 773-42A

S. R. Reed, 704-56E

K. A. Roberts, 773-43A

R. R. Seitz, 773-43A

D. F. Sink, 704-56E

F. G. Smith, 703-41A

R. F. Swingle, 773-43A

G. A. Taylor, 773-43A

K. L. Tempel, 704-56E

C. Wilson (1 file copy \& 1 electronic copy), 773-43A - Rm. 213 